\title{
The Informativeness of U.S. Banks' Statements of Cash Flows
}

\author{
Zhan Gao* \\ Lancaster University \\ Weijia Li \\ Lancaster University \\ John O'Hanlon \\ Lancaster University
}

This version: February 2019

* Corresponding Author

We thank the Editor, Jenny Tucker, and an anonymous reviewer for their valuable inputs. 


\title{
The Informativeness of U.S. Banks' Statements of Cash Flows
}

\begin{abstract}
Banks, financial statement users, and accounting standard setters have long disagreed on the informativeness of banks' statements of cash flows (SCFs) and there is a lack of relevant evidence in the literature. This paper examines the informativeness of the SCFs of U.S. commercial banks in two settings where SCFs are purported to be useful. The first analysis tests the incremental value relevance of banks' SCFs beyond income statements and balance sheets and compares bank's SCFs with those of industrial firms. We find that banks' SCFs have limited incremental value relevance, and are much less value relevant than industrial firms' SCFs. The second analysis examines and finds no distress-predictive power of banks' SCFs, especially in the presence of standard distress predictors. Overall, our results are consistent with the view that banks' SCFs have limited informativeness.
\end{abstract}

Keywords: statement of cash flows; banks; value relevance; distress prediction JEL code: G21; M41 


\section{Introduction}

Since SFAS 95 took effect in 1988, U.S. GAAP has required U.S. banks, like industrial firms, to provide a statement of cash flows (SCF) that categorizes cash flows as relating to operating, investing or financing activities. International Financial Reporting Standards (IFRS) have included a similar requirement for banks and other firms under their jurisdiction from $1994 .{ }^{1}$ However, banks have always argued that, unlike the SCFs of industrial firms, theirs provide little additional information because cash flow is not a useful measure of operating performance or financial condition for banks. ${ }^{2}$ Moreover, they argue that distinctions between operating, investing and financing activities are not as meaningful for banks as for industrial firms. Nonetheless, accounting standard setters continue to require banks to provide SCFs. The long-standing debate regarding the informativeness of banks' SCFs and the lack of empirical evidence on this matter motivate the current study.

We empirically investigate the informativeness of banks' SCFs in two settings where SCFs are purported to be useful. First, we examine the value relevance of banks' SCFs, incremental to their income statements and balance sheets. To do so, we first follow prior literature (e.g., Barth, Beaver, Hand and Landsman, 1999) and decompose net income into operating accruals and cash flow from operations (CFO). This decomposition only

1 Under both U.S. GAAP and IFRS, firms may choose to report cash flows from operations directly (the "direct method") or to adjust accounting income to cash flows from operations (the "indirect method"). The vast majority of firms, including banks, in the U.S. and most other countries (an exception being Australia) use the indirect method.

2 This argument appears, for example, in responses to a joint FASB/IASB Discussion paper on Financial Statement Presentation (FASB, 2008; IASB, 2008). Also, EFRAG (2015) provides a good summary of banks' objections. 
considers the operating section of the SCF and could be incomplete for banks, due to the concern regarding the arbitrariness of categorizing banks' operating, investing and financing items. Therefore, we develop formulas that relate net income to all three sections of the SCF, which can be viewed as generalizing the decomposition of net income. To examine the claim that SCFs are useful for industrial firms but not for banks, we compare banks' SCF items with those of industrial firms in terms of incremental value relevance. Based on a sample of U.S. banks from 2004 to 2016, we find that, in stark contrast to their counterparts in industrial firms' SCFs, there is little evidence that aggregate items (i.e., subtotals) in banks' SCFs are incrementally value relevant in the presence of net income and book value of equity. This is also true of individual items in banks' SCFs. There is some indication that banks' SCFs are marginally value relevant during the 2008 financial crisis. We also find evidence that, in contrast to industrial firms, the distinction between operating and non-operating (investing and financing) elements of SCFs is uninformative for the valuation of banks.

Second, we examine the distress prediction power of banks' SCFs during the 2008 financial crisis and its immediate aftermath. This analysis is partly motivated by our finding that banks' SCFs are marginally value relevant during the crisis period, and also by the standard setters' view that SCFs may be used to assess banks' long-term survival prospects (FASB 1987, para. 59). We find no evidence that SCF items are useful to predict bank distress in the presence of standard predictors, including size, tier-1 capital ratio, nonperforming loans, leverage, etc. Hence, consistent with the preceding value- 
relevance results, the distress prediction results indicate limited informativeness of banks' SCFs.

This paper makes several contributions. First, it fills a gap in the literature concerning the informativeness of banks' SCFs. The findings suggest that banks' SCFs are not informative in the primary applications where they are purported to be useful. Second, the evidence in this paper is relevant to the ongoing debate on the presentation of bank SCFs, which concerns banks, financial statement users and standard setters alike. While the results here do not suggest that banks should be exempted from publishing SCFs, one policy implication may that banks could be allowed to publish SCFs in a tailored format, so that they could use reporting resources more productively. As a broader implication in the context of standard setters' consideration of a financial reporting model that would distinguish operating, investing and financing activities in the income statement and the balance sheet in a similar way to the SCF, it may be of limited use to require banks to present their income statement and balance sheet in such a way. Third, the paper develops new formulas that relate net income to all three sections of the SCF, which generalizes the decomposition of net income and may be useful to those interested in using SCF information to value banks and other firms.

The remainder of this paper is organized as follows. Section 2 summarizes accountingstandard-setting activity in relation to banks' SCFs and reviews relevant literature. Section 3 describes the research design for our value-relevance tests, Section 4 describes the sample and the data for our value-relevance tests, and Section 5 reports the results of these 
tests. Section 6 describes and reports tests of the distress-predictive power of banks' SCFs. Section 7 concludes.

\section{Background and prior literature}

\subsection{Standard setting activities of banks'SCFs}

Since the requirement to publish SCFs was first proposed in the 1980s, banks and their representatives have argued that SCFs are not as meaningful for banks as for industrial firms (FASB, 1987, para. 58-65; comment letters on a joint FASB/IASB 2008 discussion paper). ${ }^{3}$ One common argument is that cash flow is not particularly useful for analyzing a bank's performance and prospects, especially compared to cash flow of industrial firms. Another argument is that the distinctions that are made in SCFs between operating, investing, and financing cash flows are not as clear-cut for banks as for industrial firms. Related to this, differences between banks' net income and CFO are largely caused by changes in financial assets (liabilities), which are "cash-like". In contrast, the differences between industrial firms' net income and CFO are largely related to depreciation, changes in working capital and other operating items that are clearly different from cash. Despite the strong reservations by banks and associated bodies, standard setters are not convinced and continue to require that banks publish SCFs in much the same way as industrial firms. $^{4}$

3 The comment letters elicited by FASB (2008) and IASB (2008) are available at http://www.fasb.org/jsp/FASB/CommentLetter_C/CommentLetterPage\&cid=1218220137090\&project id $=1630-100$.

4 For example, FASB (1987) argues that '[w]hile a bank is unique in the sense that cash can be viewed as its product, a bank needs cash for essentially the same reasons a manufacturer does - to invest in its 
The SCF in general and banks' SCF in particular have been considered in ongoing projects by the FASB and the IASB, and will likely continue to be considered in the future. ${ }^{5}$ While the standard setters show little appetite for exempting banks from providing an SCF, they accept that needs for the SCF are different for financial from those for nonfinancial firms. ${ }^{6}$ Moreover, they appear to be open to suggestions that may improve the usefulness of banks' SCFs, which range from radical changes, such as the replacement of the SCF by a statement of changes in highly liquid assets or by a flow statement for regulatory capital, to incremental changes, such as the removal of the categorization of activities (EFRAG, 2015). The results in our paper can form part of the evidence pool that assists the standard setters in their deliberations. More broadly, accounting standard setters are considering moves towards a reporting model where, similar to the SCF, the income statement and the balance sheet would distinguish between operating, financing and investing activities. ${ }^{7}$ One implication of this study’s results is that, for banks, distinguishing these activities in the other two primary financial statements may also be of limited usefulness.

operations, to pay its obligations, and to provide returns to its investors.' (FASB, 1987, para. 59). The IASB makes a similar argument (IASB, 2016, para. 3).

5 In 2004, the FASB and IASB started a joint project to improve the presentation of financial statements, including the SCF. This joint project has since been succeeded from 2014 by a FASB project on financial performance reporting and by a broader-scoped IASB project on primary financial statements. Also, in 2017 the FASB initiated a research project on targeted improvements to the statement of cash flows.

6 See FASB codification topic 230 and topic 942 and the illustrative examples in IAS 7 (IASB, 2016).

7 See, for example, FASB (2016), as well as papers for the IASB meeting on its primary financial statements project held in December 2018. 


\subsection{Prior literature}

This paper draws on two streams of accounting literature: the value relevance of SCFs and the prediction of financial distress using SCF items. In the first stream of literature, numerous previous studies have examined the value relevance of the SCFs of industrial firms and found that valuation multiples on (operating) accruals are lower than those on CFO (e.g., Livnat and Zarowin, 1990; Dechow, 1994; Akbar, Shah and Stark, 2011). There is limited research, however, on the value relevance of banks' SCFs. Barth et al. (1999) examine the value relevance of accruals and CFO by sectors. They show that the valuation multiples on CFO and on accruals are less different from each other in the financial-institutions sector than in other industrial sectors. For a small sample of large U.S. banks with significant trading activities, Ryan, Tucker and Zarowin (2006) analyze the association between stock returns and cash and accrual components of net income, which are obtained from SCFs. They find that returns are more highly associated with components relating to operating activities than with components relating to non-operating (trading) activities.

More closely related to ours, a study by Burke and Wieland (2017; henceforth BW) finds that CFO and accruals of US banks are both value relevant. Our paper differs from BW in several key aspects. First, the main focus of our value-relevance analysis is on the incremental value relevance of bank SCFs, especially beyond income statements. Second, our paper considers the information in an entire SCF, whereas BW only focuses on the information in an SCF's operating section. Third, our paper compares banks' SCFs with 
those of industrial firms', which BW does not do. Lastly, our paper also examines the distress predictive ability of banks' SCFs, which BW does not do either.

The second stream of relevant literature concerns the prediction of financial distress using financial statement items, especially involving cash flows and banks. Cash flows have been shown to have distress-predictive power for companies in general (Jones and Hensher, 2004) and industrial firms in particular (Schellenger and Cross, 1994). Using pre-SFAS-95 data, previous research has also found that self-constructed cash flows (i.e., not directly from the SCF) have predictive power for financial institutions' distress (e.g., Henebry, 1996; Catanach, 2000). Our paper differs from these studies by examining the distress-predictive power of SCF items, which are more precise measures of cash flow and related items.

\section{Research design for value-relevance tests}

\subsection{SCF items and their relations with net income}

Our empirical analyses center on extracting information from banks' SCFs. One of the primary contributions of an SCF (in the indirect form) is allowing users to decompose net income into a cash component (CFO) and an accrual component (operating accruals), which have distinctive implications for stock markets (Sloan, 1996). This relation can be written as follows:

$$
N I \equiv C F O+O P A,
$$


where $N I$ is net income, $C F O$ is operating cash flow, and $O P A$ is operating accruals. ${ }^{8}$

While widely used (e.g., Barth et al. 1999; Hribar and Collins 2002), the relation (IC.0) only utilizes an SCF's operating section and ignores the investing and financing sections, which could potentially contain useful information. Moreover, because the distinctions between banks' operating, investing, and financing items are not clear-cut (Ryan, 2007), focusing exclusively on the operating section risks discarding an arbitrarily determined subset of the information in an SCF. Instead, we seek to include all three sections of an SCF, which allows us to obtain evidence on the usefulness of an SCF as a whole, as well as the usefulness of labelling items as operating versus non-operating. To do so, we note that an SCF first adjusts net income for operating accruals (under the indirect method) and then reports cash flows from investing and financing activities, and thereby arrives at the change in cash and cash equivalents as the bottom line. This process relates net income to these SCF items, which effectively generalizes the decomposition of net income (I-C.0). Specifically:

$$
N I \equiv \Delta C+O I F
$$

where $\Delta C$ is the change in cash and cash equivalents, excluding cash flows with shareholders (henceforth "non-shareholder change in cash"). ${ }^{9}$ OIF reconciles net income with non-shareholder change in cash and contains operating accruals, investing items (from the investing section) and non-shareholder financing items (i.e., cash flows with

$8 O P A$ in (I-C.0) can also be calculated as the sum of all adjustments in the operating section of the SCF (under the indirect method) times -1 . The sign reversal ensures that $O P A$ and $C F O$ add up to NI. For example, a credit sale is an increase in operating accruals, but it is a negative adjustment in the SCF.

9 Cash flows with shareholders include equity issues, dividend payouts and share repurchases. 
debtholders from the financing section). ${ }^{10}$ Let $I F$ be all non-operating items (i.e., the sum of investing and non-shareholder financing items), $O I F \equiv O P A+I F$. This gives:

$$
N I \equiv \triangle C+O P A+I F
$$

We choose not to decompose non-operating items $I F$ because banks' investing items are almost indistinguishable from non-shareholder financing items (Ryan et al., 2006). ${ }^{11}$

The income-cash relations (I-C.0), (I-C.1) and (I-C.2) apply to both banks and industrial firms in the value-relevance analysis in Section 5. They are also used in the distress-prediction analysis in Section 6 (applied to banks only).

Finally, we consider the possibility that, although aggregate SCF items might not be meaningful for banks, individual items in banks' SCFs might still be useful (Ryan, 2007). This leads to the following income-cash relation:

$$
\begin{aligned}
N I \equiv & \Delta C+L O A N \_H F S+L L P+S E C \_G L+T R A D \_O T H+O T H E R \_O \\
& +L O A N \_H F I+S I N V+D E P O S I T+D E B T+O T H E R \_I F,
\end{aligned}
$$

where $L O A N \_H F S=$ change in loans held-for-sale; $L L P=$ loan-loss provision; $S E C \_G L=$ investment security gains and losses; TRAD_OTH = net change in trading and other assets and liabilities; OTHER_O= other operating accruals; $L O A N \_H F I=$ change in loans held for investment; SINV = change in investments; DEPOSIT = decrease (increase) in deposits; $D E B T=$ decrease (increase) in current and long-term debt; OTHER_IF = other

${ }^{10}$ Investing and non-shareholder financing items are equal to the corresponding cash flows times -1 . We reverse the signs of these cash flows so that all operators in (I-C.1) and (I-C.2) are plus. Because investing and non-shareholder financing items correspond to long-term operating assets (e.g. PPE) and financing items (e.g., debt), they can be thought of as generalized "accruals", just as a change in working capital corresponds to operating accruals. For example, the acquisition of PPE, a cash outflow (negative) in the SCF, increases long-term operating assets, which will be recorded as an expense in the future, just as a prepaid expense is.

11 In our sample, the correlation between banks' investing and non-shareholder financing items is about -0.9 . 
investing and financing items. ${ }^{12}$ Consistent with the preceding income-cash relations, all right-hand-side items (except $\Delta C$ ) are equal to the respective SCF item times -1 .

\subsection{Value-relevance regression models}

Our first empirical analysis examines the incremental value relevance of bank SCF items beyond net income. Value-relevance analysis has long been used to evaluate the informativeness of accounting information for valuation purposes (e.g., Aboody and Lev, 1998; Barth, Beaver and Landsman, 1998; Brown and Sivakumar, 2003; Collins, Maydew and Weiss, 1997; Collins, Pincus and Xie, 1999; Francis and Schipper, 1999). The basis for value-relevance analysis is the equity valuation model of Ohlson (1995), stated here in the form of a regression:

$$
M V=v_{0}+v_{1} N I+v_{2} B V
$$

where $M V$ is market value of equity, $N I$ is net income, and $B V$ is book value of equity. The coefficients $v_{1}$ and $v_{2}$ can be interpreted as valuation multiples for relevant items.

To examine whether the operating section of the SCF is incrementally value relevant, we modify regression 1 using the decomposition (I-C.0):

$$
M V=\alpha_{0}+\alpha_{1} O P A+\alpha_{2} N I+\alpha_{3} B V
$$

The coefficient for $O P A\left(\alpha_{1}\right)$ captures the incremental valuation multiple for operating accruals over CFO and the coefficient for $N I\left(\alpha_{2}\right)$ captures the valuation multiple for CFO, which is the one component of net income that is omitted from the regression. ${ }^{13}$ In other

\footnotetext{
12 All individual items add up to $O I F$. Moreover:$$
O P A=L O A N \_H F S+L L P+S E C \_G L+T R A D \_O T H+O T H E R \_O
$$$$
I F=L O A N \_\overline{H F I}+S I N V+D E P O \bar{S} I T+D E B T+{ }^{-} \text {OTHER_IF } .
$$

13 To see this, substitute $N I$ in regression 2 with $C F O+O P A$ to obtain:

$$
M V=\alpha_{0}+\left(\alpha_{1}+\alpha_{2}\right) O P A+\alpha_{2} C F O+\alpha_{3} B V .
$$
}


words, a significant $\alpha_{1}$ indicates that the valuation multiples on $C F O$ and $O P A$ are different from each other. Because $C F O$ and $O P A$ are only available in the operating section of an SCF, this serves as evidence that the SCF is incrementally informative for valuation purposes, beyond income statements and balance sheets. Previous research documents that industrial firms' operating accruals have a lower valuation multiple than their CFO (Sloan, 1996; Barth et al., 1999), so to the extent that banks behave like industrial firms, $\alpha_{1}$ is expected to be negative.

To examine whether an entire SCF is incrementally useful for valuation purposes, we use the income-cash relation (I-C.1) to modify regression 1:

$$
M V=\beta_{0}+\beta_{1} O I F+\beta_{2} N I+\beta_{3} B V
$$

where $O I F$ sums all SCF items between net income and non-shareholder change in cash $(\Delta C)$. We are interested in the coefficient for $\operatorname{OIF}\left(\beta_{1}\right)$, which captures the incremental valuation multiple for $O I F$ over $\Delta C{ }^{14}$ A significant $\beta$ 1 suggests that the two elements of $\mathrm{SCF}-\triangle C$ and $O I F$ - have different valuation coefficients and therefore should be treated differently. In turn, it implies that the SCF is useful in providing users with the information about such elements.

To examine whether distinguishing operating and non-operating items is informative, we use the income-cash relation (I-C.2) to modify regression 1:

Moreover, in a regression of $M V$ on $O P A$ and $C F O$, significant coefficients on $O P A$ and $C F O$ are not evidence that the SCF is incrementally value relevant; such an implication can only be drawn from the inequality of the two coefficients.

${ }^{14}$ Using (I-C.1), we substitute $N I$ in regression (3) with $\Delta C+O I F$, leading to a regression equivalent to (3): $M V=\beta_{0}+\left(\beta_{1}+\beta_{2}\right) O I F+\beta_{2} \Delta C+\alpha_{3} B V$.

It is evident that the valuation multiple of $O I F$ is $\beta_{1}+\beta_{2}$;, and that of $\Delta C$ is $\beta_{2}$; so $\beta_{1}$ is the incremental valuation multiple for $O I F$ over $\triangle C$. 


$$
M V=\gamma_{0}+\gamma_{1} O P A+\gamma_{2} I F+\gamma_{3} N I+\gamma_{4} B V .
$$

The coefficients for $O P A$ and $I F\left(\gamma_{1}\right.$ and $\left.\gamma_{2}\right)$ are the incremental valuation multiples for operating accruals and non-operating items, respectively, over $\Delta C$; the coefficient for $N I$ $\left(\gamma_{3}\right)$ is the valuation multiple for $\Delta C$. Here, we can test whether the valuation multiples for $O P A$ and $I F$ are equal to each other.

Finally, to examine the informativeness of individual items in banks' SCFs, we use (IC.3) to modify regression 1 :

$$
\begin{aligned}
& M V=c_{0}+c_{1} L O A N \_H F S+c_{2} L L P+c_{3} S E C \_G L+c_{4} T R A D \_O T H+c_{5} O T H E R \_O+ \\
& c_{6} L O A N \_H F I+c_{7} S I N V+c_{8} D E P O S I T+c_{9} D E B T+c_{10} O T H E R \_I F+c_{11} N I+c_{12} B V .(5)
\end{aligned}
$$

As before, the coefficient for an individual item is the incremental valuation multiple on the item over $\Delta C$, and its significance indicates the incremental value relevance of the item. Because the first five items ( $\left.L O A N_{-} H F S, L L P, S E C \_G L, T R A D \_O T H, O T H E R \_O\right)$ add up to $O P A$, we expect their coefficients to be negative, by referencing the expected sign of the $O P A$ coefficient in regression 2. The other items are non-operating, about which we do not have directional predictions.

In regressions $2-5, M V$ is measured at the end of the fourth month after the end of fiscal year $t$ so that it reflects information in year $t$ 's annual financial statements. ${ }^{15} \mathrm{NI}$ is income before extraordinary items in year $t$, and $B V$ is common equity at the end of year $t$.

\footnotetext{
15 This is done by multiplying the market value at the fiscal year end by the return on the firm's shares between the fiscal year end and the end of the fourth month after that year end. This procedure adjusts for any capital issues or distributions that may have occurred during that interval.
} 
All variables are scaled by lagged total assets. ${ }^{16,17}$ Because the valuation multiple on net income (book value) is likely to be lower (higher) for loss firms than for profitable firms (Burgstahler and Dichev, 1997), we include an indicator for loss and let it interact with all the independent variables:

$$
\begin{gathered}
M V=\alpha_{0}+\alpha_{1} O P A+\alpha_{2} N I+\alpha_{3} B V+ \\
\alpha_{4} L O S S+\alpha_{5} O P A \times L O S S+\alpha_{6} N I \times L O S S+\alpha_{7} B V \times L O S S
\end{gathered}
$$

where LOSS is equal to one if a firm-year reports a loss and zero otherwise. Our main focus of interest is still the coefficient for $O P A\left(\alpha_{1}\right)$, which now reflects the incremental valuation multiple for operating accruals over CFO for profit firm-years. The coefficient $\alpha_{1}+\alpha_{5}$ is the counterpart for loss firm-years. ${ }^{18}$ In light of prior evidence (e.g., Burgstahler and Dichev 1997), $\alpha_{1}\left(\alpha_{5}\right)$ is expected to be negative (positive), $\alpha_{2}\left(\alpha_{6}\right)$ is expected to be positive (negative), and $\alpha_{3}$ and $\alpha_{7}$ are expected to be positive.

We estimate regressions 2-4 separately for banks and industrial firms, and test for the equality of coefficients between the two types of entities. ${ }^{19}$ Regression 5 is only estimated

16 Scaling by total assets causes intercept terms to differ between banks and industrial firms because, on average, banks have much higher leverage than industrial firms and, consequently, much lower totalasset-scaled accounting numbers. Scaling intercept terms would eliminate this effect. Our reported results are based on regression models with unscaled intercepts. As reported subsequently, a robustness test showed that our inferences are not sensitive to whether or not intercept terms are scaled.

17 Barth and Kallapur (1996) recommend dealing with scale issues in regression models by including a scale proxy as an independent variable. Untabulated tests show that our inferences are robust to the alternative method recommended by those authors.

18 Estimating regression $2^{\prime}$ for the whole sample is equivalent to estimating regression 2 for the profit sample and loss sample separately.

19 To test the equality of coefficients between banks and industrial firms, we estimate models (2), (3) and (4) for a combined sample of banks and industrial firms, including a binary variable to indicate entity type (and let the entity-type indicator interact with all independent variables, including loss-related ones). The significance of the interaction term between a firm-type indicator and an independent variable indicates whether the coefficient for that variable is significantly different between the two types of entity. 
for banks because items are bank-specific. All regressions include year fixed effects and $t$ statistics are based on White standard errors that are clustered by firm.

\section{Sample, data and descriptive statistics for value-relevance analyses}

The accounting data for banks are from Compustat Bank and those for industrial firms from Compustat; stock return data are from CRSP. Compustat Bank only provides SCF data for banks from 2004, which limits the starting point of the sample. The initial sample includes all U.S. publicly listed commercial banks (SIC code 602) and industrial firms (in other SIC codes) from 2004 to 2016. The sample firms satisfy the following selection criteria: (i) required data are available; (ii) share price of more than $\$ 1$; and (iii) positive book value of equity. The final sample consists of 4,450 bank-years (594 different banks) and 33,849 industrial-firm-years (5,217 different industrial firms). The Appendix details the construction of the variables. To mitigate the impact of outliers, the most extreme $2 \%$ of all (scaled) variables are winsorized. ${ }^{20}$

Table 1 reports the sample composition for value-relevance analyses. Panel A summarizes the numbers of firm-year observations by year for banks and industrial firms, as well as by profit and loss. The percentages of losses in banks increase very substantially from $1.5 \%$ in 2006 to $7.9 \%$ in 2007 , triple to above $25 \%$ for $2008-2010$, and then fall

20 To maintain the relations between accounting variables as prescribed by (I-C.0)-(I-C.3), we keep one variable unwinsorized, but calculate it using one of the income-cash-relations. For example, we winsorize $N I$ and $C F O$ by the most extreme $2 \%$ and then calculate $O P A$ using (I-C.0). Regarding the individual items used in model (5), we winsorize each item belonging to OPA (IF) except for OTHER_O (OTHER_IF); OTHER_O $\left(O T H E R \_I F\right)$ is then calculated as winsorized OPA $(I F)$ minus the sum of the winsorized items. In robustness tests, we use other winsorization methods: winsorizing the most extreme $2 \%$ of cases year-by-year; winsorizing the top and bottom $1 \%$ both for pooled data and year-by-year. Inferences are robust to these alternative winsorization methods. 
substantially to about $12 \%$ in 2011 and about $2 \%$ in 2016 . While the Bank for International Settlements (2010, page 10) sees the financial crisis as lasting from 2007 to 2009 , the panel shows the continuing high proportions of bank losses in 2010. Thus, we treat 2007 to 2010 as the crisis sub-period in our value-relevance analysis. Panel B summarizes the numbers of industrial firms and firm-year observations by SIC Code.

In Table 2, Panel A reports descriptive statistics for (unwinsorized) firm characteristics for banks and industrial firms: market capitalization (at fiscal year end), book value of equity, total assets, and leverage. As expected, the mean and median leverages of banks are much higher than the corresponding statistics for industrial firms. Panel B reports descriptive statistics for the regression variables used in regressions 2-4, and Panel C reports the correlations between these variables. Panel $\mathrm{C}$ reveals some striking contrasts between banks and industrial firms. For example, the Spearman correlation coefficient between $O P A$ and $C F O$ is -0.775 for banks, but only -0.034 for industrial firms. The high negative $O P A-C F O$ correlation for banks is consistent with many of banks' operating accruals being financial in nature and relatively indistinguishable from CFO; instead CFO and operating accruals largely substitute for each other. This high negative correlation for banks contrasts with the much lower negative correlation for industrial firms whose operating accruals are predominantly non-financial in nature and distinctive from cash.

The implication is that the SCF is likely to be less informative for banks than for industrial firms. Another noticeable difference between banks and industrial firms is the correlation between non-shareholder change in cash $(\Delta C)$ and non-operating items $(I F)$ : it is -0.921 
for banks, but only -0.619 for industrial firms. Panel D reports descriptive statistics for the bank-specific regression variables in regression 5.

\section{Incremental value relevance of banks' SCFs: Empirical results}

Table 3 reports the results of value-relevance tests for banks and industrial firms, in which we regress market value on SCF items in the presence of net income and book value. ${ }^{21}$ Panel A reports the results from estimating regressions $2-4$ over the overall sample period of 2004-2016. Here and in subsequent tables, our discussion focuses on profit firms, which are the majority of the sample; the inferences for loss firms are similar. In regression 2, our interest lies in the coefficient for $O P A$, which, if significant, indicates that, for profitable firms, the valuation multiple for operating accruals differs from that for CFO. In the "Banks" column, the coefficient for $O P A$ is negative and marginally significant $(-0.160, p<0.05)$, indicating that, for profitable banks, the valuation multiples for operating accruals and CFO are only marginally different from each other, which renders SCF weakly informative. In contrast, in the "Industrial" column, the $O P A$ coefficient is much larger in magnitude and highly significant $(-3.992, p<0.01)$, suggesting that, for profitable industrial firms, the valuation multiple for operating accruals is significantly lower than that for CFO. The "Diff $(p)$ " column confirms that the $O P A$ coefficient for banks is significantly smaller than that for industrial firms $(p<0.01)$. The implication of these findings is that the operating section of SCF is substantially less

21 As we seek to present strong and robust evidence of statistical significance, the text primarily focuses on results that are significant at least at 5\%. 
informative for banks than for industrial firms. These findings echo the differential $O P A$ CFO correlations between the two types of entities (Panel C, Table 2) and could be rooted in the claimed difference between the operations of banks and industrial firms.

Regressions 3 and 4 in Panel A are motivated by the suggestion that the distinction between banks' operating and non-operating items, as currently presented, is arbitrary. Unlike regression 2, the cash-flow construct in regression 3 is non-shareholder change in cash $(\Delta C)$, and $O I F$, which combines operating accruals with non-operating items, replaces $O P A$. The inferences from regression 3 also point to the lack of informativeness of banks' SCFs. For example, the OIF coefficient is insignificant for profitable banks $(-0.041, p>0.1)$, but strongly significant for profitable industrial firms $(-0.688$, $p<0.01)$. Unsurprisingly, the $O I F$ coefficients are significantly different between the two types of entities $(p<0.01)$.

In regression 4, where $O I F$ is decomposed into $O P A$ and $I F$, the $O P A$ coefficient for profitable banks is marginally significant $(-0.192, p<0.05)$, similar to its counterpart in regression 2. Nonetheless, banks' $O P A$ coefficient is still significantly smaller in magnitude than industrial firms' $(p<0.01)$, thus corroborating the key inference from the preceding two regressions. Moreover, the $I F$ coefficients for banks and industrial firms are both insignificant ( -0.037 and 0.008 , respectively; $p>0.1$ for both), and they are not significantly different from each other $(p=0.821)$. Additional tests on the equality of the $O P A$ and $I F$ coefficients (reported in the bottom-right of Panel A) show that the coefficients for $O P A$ and $I F$ are weakly distinguishable from each other for profitable 
banks $(p=0.054)$, but they are significantly different for profitable industrial firms $(p<0.01)$. This is yet further evidence that the distinction between operating and nonoperating elements of banks' SCFs is uninformative.

Panels B-D in Table 3 report the results from estimating regressions 2-4 separately for the three sub-periods: the pre-crisis period (2004-2006), the crisis period (2007-2010), and the post-crisis period (2011-2016). Interestingly, for banks, the coefficients for variables of interest- $O P A, O I F$ and $I F$ - are marginally significant only in the crisis period, but not in the pre- and post-crisis periods. Specifically, Panel C shows that, for profitable banks during the crisis period, the $O P A$ coefficient is marginally significant in regression $2(-0.226, p<0.1)$, the OIF coefficient is significant in regression $3(-0.103, p$ $<0.05)$, and the $O P A$ and $I F$ coefficients are both significant $(p<0.05)$ in regression 4. The inference is that banks' SCFs could be more useful for investors in a highly uncertain and challenging environment, presumably by assisting investors to assess banks' chances of survival. Despite these limited improvements during the financial crisis, banks' SCFs are still far less value relevant than industrial firms', and that is true in all sub-periods.

To summarize, the results in Table 3 suggest that, as far as aggregate SCF items are concerned, banks' SCFs provide little useful information for valuation, especially in the presence of income statements and balance sheets, which is in stark contrast to industrial firms' SCFs. Nevertheless, there is some indication that banks' SCFs are more value relevant during the financial crisis. ${ }^{22}$

22 Our results are qualitatively comparable to those in Burke and Wieland (2017), which show positive and significant coefficients for CFO. However, unlike Burke and Wieland (2017), we do not find that 
Table 4 reports the results from estimating regression 5, which examines the incremental value relevance of individual items in banks' SCFs over the whole period and the three sub-periods. For profitable banks, only the coefficients for SEC_GL (gains and losses from investment securities), OTHER_O (other operating accruals), and DEPOSIT (changes in deposits) are statistically significant over the whole period, indicating that the valuation multiples for these items differ from that for $\Delta C$. These items (except OTHER_O), however, are not consistently significant in all sub-periods. Therefore, the main inference from the individual-item results are consistent with those from the aggregate-item results in Table 3: banks' SCFs are uninformative for valuation purposes.

We implement a number of robustness tests. First, we construct alternative samples: negative book-value cases are included; and cases of mergers and acquisitions (during the financial crisis) are excluded. Second, we also implemented a returns specification similar to the one in Ryan et al. (2006). ${ }^{23}$ Our inferences are robust from these alternative specifications.

Overall, the value-relevance analyses find that banks' SCFs have limited incremental informativeness for the purpose of valuation, and they are much less informative than industrial firms' SCFs. Interestingly, banks' SCFs are moderately value relevant during

coefficients for CFO are significantly higher than those for operating accruals. One possible cause of this discrepancy is model specification: while Burke and Wieland (2017) control for lagged book value, we use contemporaneous book value, as in Barth et al. (1998).

23 The dependent variable is annual stock return lagged by 4 months, and the explanatory variables are the same as those in Tables 3 and 4, except for scaling by lagged market value of equity. Unlike in a levels specification, there is no role for book value within a returns specification. 
the financial crisis, which partially motivates the subsequent analysis of the predictive ability of bank SCFs for distress in the financial crisis and the aftermath.

\section{Predictive ability for distress of banks' statements of cash flows}

In this section, we examine the distress-predictive power of banks' SCFs during the financial crisis of the late 2000 s and its immediate aftermath. Our aim is to assess parsimoniously the incremental distress-predictive power of items in banks' SCFs, rather than provide a comprehensive model for bank-distress prediction. This examination is motivated by several considerations. First, the evidence from the preceding valuerelevance analysis suggests that banks' SCFs are moderately value relevant during the financial crisis (but not in the other periods), suggesting that SCFs could have been useful to infer banks' survival prospects in that challenging business environment. Second, standard setters claim distress-predictive power as one of the key benefits provided by SCFs. FASB argues that "to survive, a bank-like a manufacturer-must generate positive (or at least neutral) cash flows from its operating, investing and financing activities over the long run" (FASB, 1987, para. 59). In contrast, banks maintain that the information in SCFs is of little help in assessing a bank's future financial health. ${ }^{24}$ Interestingly, the FR Y-9C regulatory reports that bank holding companies file with the Federal Reserve

${ }^{24}$ For an example of this argument, see the comment letter from the European Banking Federation (letter 61) in response to a discussion paper of the joint FASB/IASB project on financial-statement presentation (FASB, 2008; IASB, 2008). It is available at

http://www.fasb.org/jsp/FASB/CommentLetter_C/CommentLetterPage\&cid=1218220137090\&project id $=1630-100$. 
System do not include SCFs, suggesting that bank regulators have a different view from standard setters and do not see SCFs as important (for bank supervision).

\subsection{Sample, data, and distress prediction models}

Following Ng and Roychowdhury (2014), we use information available in 2007 to predict distresses that occur from 2008 to 2010. Similar to the value-relevance analysis, the 2008-2010 period is based on the standard timing of the 2008 financial crisis (e.g., Bank for International Settlements, 2010), but it is modified by the fact that, in our data, 2010 is the year with the most distress cases, a feature probably due to the time lag from initial impact to confirmed distress. ${ }^{25}$

The sample used in this analysis comprises the 382 banks in 2007 that are used in our value-relevance analysis (see Table 1, Panel A and Table 5, Panel A). We define a bank as distressed if it or, in the case of a bank-holding company, any of its banking subsidiaries entered into receivership under the Federal Deposit Insurance Corporation (FDIC) between 2008 and $2010 .{ }^{26}$ We identify 36 distress cases out of the 382 in our sample (9.42\%), of which 15 and 21 cases entered receivership in 2009 and 2010, respectively.

We follow the extensive distress prediction literature and employ a logit regression model as follows: $:^{27}$

$$
\text { DISTRESS } 2008-10=b_{0}+\sum_{n} \delta_{n} S C F_{-} I_{T E M}, 2007+b_{1} N_{2007}+b_{2} T A R P_{2007}+
$$

25 Specifically, there are no distress cases in 2007 or 2008, 15 in 2009, 21 in 2010; then, the number of distress cases tails off, with 9 in 2011 and 3 in 2012.

26 Distress cases are available at http://www.fdic.gov. About $97 \%$ of the 382 cases are bank holding companies.

27 Another distress-prediction model commonly used in the literature is the Cox proportional hazard model (Shumway, 2001; Ng and Roychowdhury, 2014). The unreported results and inferences from that model are very similar to those arising from estimating model (6). 


$$
b_{3} S_{Z I Z E} 2007+b_{4} T I E R 1_{2007}+b_{5} N P L_{2007}+b_{6} L E V E R A G E_{2007}
$$

where the dependent variable DISTRESS $2008-10$ is equal to one if a bank experiences distress between 2008 and 2010, and zero otherwise. Our main interest is items in banks' SCFs (SCF_ITEM). The exact variables vary depending on which form of income-cash relation is involved. Thus, SCF_ITEM can be (each as a version of regression 6): (i) OPA (I-C.0); (ii) $O I F$ (I-C.2); (iii) $O P A$ and IF (I-C.2); and (iv) $L O A N \_H F S, L L P, S E C \_G L, T R A D \_O T H$, OTHER_O,LOAN_HFI, SINV,DEPOSIT, DEBT, OTHER_IF (I-C.3).

Additional predictors in regression 6 are widely used in prior literature. TARP is an indicator variable, which is equal to one if a capital infusion was received under the U.S. Treasury's Troubled Asset Relief Program (TARP), and zero otherwise. ${ }^{28}$ TARP capital infusions are expected to be negatively associated with future distress, because they were more likely to be granted to banks that, despite being poorly capitalized, had a relatively sound underlying business (Bayazitova and Shivdasani 2012; Ng and Roychowdhury 2014). The rest of the predictors are size (SIZE), tier 1 capital ratio (TIER1), nonperforming loans (NPL), and leverage (LEVERAGE). The Appendix details the construction of the control variables. All of the predictors except TARP and SIZE are multiplied by 100 so that the coefficients are of more readable magnitudes. The most extreme $2 \%$ of cases for each continuous predictor (except TARP) are winsorized. Panel B of Table 5 reports descriptive statistics for the variables in regression 6.

28 TARP operated between October 2008 and December 2009 to help commercial banks weather liquidity shocks during the financial crisis. Data on TARP participation were obtained from U.S. Treasury financial stability reports (available at http://www.treasury.gov/initiatives/financial-stability/Pages/default.aspx). Unlike the other control variables, TARP is not a predictor: it controls for an event during the distressprediction period, rather than something that was observable at the end of 2007. 


\subsection{Results}

Panel $\mathrm{C}$ in Table 5 reports results estimating the logistic regression 6, in which columns (6.i)-(6.iii) concern aggregate SCF items and column (6.iv) concerns individual SCF items. Regardless of specific income-cash relations, items in bank SCFs show no predictive power for future distress, raising a question over the claims for such a benefit. ${ }^{29}$ These results are in contrast to those in the literature, although major methodological differences exist between those studies and ours: Henebry (1996) and Catanach (2000) report evidence for U.S. financial institutions, but use self-constructed cash flow measures (i.e., pre-SFAS-95 data); Schellenger and Cross (1994) report for U.S. industrial firms; Jones and Hensher (2004) report economy-wide Australian evidence. Among the additional predictors, the coefficient for TARP is consistently negative and significant, as expected; ${ }^{30}$ the other predictors also behave reasonably.

We conduct a number of robustness analyses. First, we repeat the distress prediction tests in subsequent years: i.e., we use data from 2008 (2009) to predict bank distress over three subsequent years. Second, we control for the influence of off-balance-sheet (OBS) items, which, due to their large magnitude and opaque nature, could be a red flag for

29 When we estimate model (6) without additional predictors (unreported), some SCF items are significant. For example, $O I F$ in (6.ii) and $I F$ (6.iii) are both significant at 5\%; so are LLP (loan-loss provision) and LOAN_HFI (change in loans held for investment) in (6.iv). However, because our purpose is to assess the incremental predictive power of bank SCFs, beyond other financial statements and other available data, those results do not constitute strong evidence for bank SCFs' usefulness.

30 Unreported results suggest that, consistent with prior evidence in Bayazitova and Shivdasani (2012) and $\mathrm{Ng}$ and Roychowdhury (2014), the banks in our sample that received TARP were those with relatively low regulatory capital but relatively strong underlying businesses. We note that the pseudo $R^{2}$ reported for models (6.i)-(6.iii) are similar to those reported for similar models in Ng and Roychowdhury (2014). 
banks' financial standing (Haq and Heaney, 2012). ${ }^{31}$ Third, we examine the distress predictive power of bank SCF items in a sample excluding the smallest banks. This analysis is motivated by the concerns that small banks have simpler funding models and cash-flow patterns and SCF might be less relevant to them than to their larger counterparts. ${ }^{32}$ Fourth, we exclude cases where mergers and acquisitions occurred during the crisis. Fifth, we apply the Cox proportional hazard model to our data. Our inferences are robust from these alternative approaches.

To summarize, we find that, controlling for other standard predictors, neither aggregate nor individual SCF items predict future bank distress. This lack of usefulness for distress prediction by banks' SCF is consistent with their uninformativeness for valuation purposes documented earlier.

\section{Conclusion}

There is a long-standing controversy regarding the usefulness of banks' SCFs. Banks have argued that the nature of their business makes their SCFs uninformative, especially compared to industrial firms' SCFs; some even suggest that banks should be exempted from publishing SCFs. As exemplified in SFAS 95 (FASB, 1987) and in recent pronouncements, accounting standard setters have not been persuaded by these arguments

31 OBS is measured as the sum of off-balance sheet items 44-53 on the FR Y-9C forms filed by bank holding companies with the Federal Reserve. For a subperiod from 2004 to 2012, this is included in models (6.i.c)-(6.iv.c) as an additional control variable. Because not all banks in our sample file FR Y9Cs, either because they are not bank holding companies (approximately 3\%) or because they are below the size threshold, the requirement for data on OBS reduces the sample slightly.

32 Distress prediction tests are not performed on the small bank sample because there are only two cases of financial distress. 
and have continued to require banks to provide SCFs. In light of the limited evidence available, calls have been made for more research on this issue (e.g., EFRAG, 2015).

In this paper, we report U.S.-based evidence relevant to the debate on the informativeness of banks' SCFs in two analyses. The first analysis tests the incremental value relevance of banks' SCFs beyond income statements and balance sheets, and compares bank's SCFs with those of industrial firms. The results suggest that U.S. banks' SCFs have limited incremental value relevance, and much less than the SCFs of industrial firms. We also find evidence that, in contrast to industrial firms, the distinction between operating and non-operating (investing and financing) elements of SCFs is uninformative for the valuation of banks.

The second analysis examines the distress-predictive power of banks' SCFs. We find no distress-predictive power of SCF items in the presence of standard predictors for bank distress. Therefore, both analyses indicate that banks' SCFs, as currently presented, lack incremental, consistent and economically identifiable benefits.

The results of this study contribute to the pool of evidence that accounting standard setters might use in their deliberations over the presentation of SCF. While we would not claim that our results justify banks being exempt from publishing SCFs, it might be worth exploring the possibility that banks be allowed to publish SCFs in a tailored format, which would result in more productive use of reporting resources. Furthermore, the evidence presented here regarding the limited benefit from distinguishing banks' activities may be relevant to those interested in using SCF information to value banks. Although this study 
is based on SCFs prepared under U.S. GAAP, the similarity between the SCF format under U.S. GAAP and under IFRS suggests that the results are also relevant to the IFRS context, a point acknowledged by EFRAG (2015). More broadly, the results of our paper also have implications for standard setters' consideration of a reporting model in which the income statement and the balance sheet might distinguish activities in a manner similar to how the SCF currently does. Our results suggest that distinguishing operating, financing and investing activities in the other two financial statements may not be as useful for banks as for industrial firms.

It should be acknowledged that our analysis is based on information from SCFs as currently constructed, and it is possible that differently constructed SCFs might provide greater evidence of informativeness. We also acknowledge that value relevance and distress-predictive power are only two criteria by which the usefulness of financialstatement information can be judged. 


\section{REFERENCES}

Aboody, D., \& Lev, B. (1998). The value relevance of intangibles: The case of software capitalization. Journal of Accounting Research, 36 (Supplement), 161-191.

Akbar, S., Shah, S., \& Stark, A. (2011). The value relevance of cash flows, current accruals, and non-current accruals in the UK. International Review of Financial Analysis, 20 (5), 311-319.

Bank for International Settlements (2010). 80 $0^{\text {th }}$ Annual Report 1 April 2009 - 31 March 2010. Basel: Bank for International Settlements.

Barth, M., Beaver, W., \& Landsman, W. (1998). Relative valuation roles of equity book value and net income as a function of financial health. Journal of Accounting and Economics, 25 (1), 1-34.

Barth, M., Beaver, W., Hand, J., \& Landsman, W. (1999). Accruals, cash flows and equity values. Review of Accounting Studies, 3 (3-4), 205-229.

Barth, M., \& Kallapur, S. (1996). The effects of cross-sectional scale differences on regression results in empirical accounting research. Contemporary Accounting Research, 13 (22), 527-567.

Bayazitova, D., \& Shivdasani, A. (2012). Assessing TARP. Review of Financial Studies, 25 (2), 377-407.

Brown, L., \& Sivakumar, K. (2003). Comparing the value relevance of two operating income measures. Review of Accounting Studies, 8 (4) 561-572.

Burgstahler, D., \& Dichev, I. (1997). Earnings, adaptation and equity value. The Accounting Review 72 (2), 187-215.

Burke, Q., \& Wieland, M. (2017). Value relevance of banks' cash flows from operations. Advances in Accounting, 39, 60-78.

Catanach Jr, A. (2000). An empirical study of operating cash flow usefulness in predicting savings and loan financial distress. Advances in Accounting, 17, 1-30.

Collins, D., Maydew, E., \& Weiss, I. (1997). Changes in the value-relevance of earnings and book values over the past forty years. Journal of Accounting and Economics, 24 (1), 3967.

Collins, D., Pincus, M., \& Xie H. (1999). Equity valuation and negative earnings: The role of book value of equity. The Accounting Review, 74 (1), 29-61.

Dechow, P. (1994). Accounting earnings and cash flows as measures of firm performance: the role of accounting accruals. Journal of Accounting and Economics, 18 (1), 3-42.

EFRAG (2015). The Statement of Cash Flows: Issues for Financial Institutions. Brussels: European Financial Reporting Advisory Group.

FASB (1987). SFAS 95: Statement of Cash Flow. Norwalk, CT: Financial Accounting Standards Board.

FASB (2008). Discussion Paper: Preliminary Views on Financial Statement Presentation. Norwalk, CT: Financial Accounting Standards Board.

FASB (2016). Invitation to Comment. Agenda Consultation. August 4, 2016. Norwalk, CT: Financial Accounting Standards Board.

Francis, J., \& Schipper, K. (1999). Have financial statements loss their relevance? Journal 
of Accounting Research, 37 (2), 319-352.

Haq, M., \& Heaney, R. (2012). Factors determining European bank risk. Journal of International Financial Markets, Institutions and Money, 22 (4), 696-718.

Henebry, K. (1996). Do cash flow variables improve the predictive accuracy of a Cox proportional hazard model for bank failure? The Quarterly Review of Economics and Finance, 36 (3), 395-409.

Hribar, P., \& Collins, D. (2002). Errors in estimating accruals: Implications for empirical research. Journal of Accounting Research, 40 (1), 105-134.

IASB (2008). Discussion Paper: Preliminary Views on Financial Statement Presentation. London: International Accounting Standards Board.

IASB (2016). IAS 7: Statement of Cash Flows. London: International Accounting Standards Board.

Jones, S., \& Hensher D. (2004). Predicting firm financial distress: A mixed logit model. The Accounting Review, 79 (4), 1011-1038.

Livnat, J., \& Zarowin, P. (1990). The incremental information content of cash-flow components. Journal of Accounting and Economics, 13 (1), 25-46.

Mulford, C., \& Comiskey, E. (2009). Cash flow reporting by financial companies: A look at the commercial banks. Atlanta, GA: Georgia Tech Financial Analysis Lab.

Ng, J., \& Roychowdhury, S. (2014). Do loan loss reserves behave like capital? Evidence from recent bank failures. Review of Accounting Studies, 19 (3), 1234-1279.

Ohlson, J. (1995). Earnings, book values and dividends in equity valuation. Contemporary Accounting Research, 1 (2), 661-687.

Ryan, S. (2007). Financial instruments and institutions: Accounting and disclosure rules ( $2^{\text {nd }}$ edition). Hoboken: John Wiley \& Sons, Inc.

Ryan, S., Tucker, J., \& Zarowin, P. (2006). Classification and market pricing of the cash flows and accruals on trading positions. The Accounting Review, 81 (2), 443-472.

Schellenger, M., \& Cross, J. (1994). FASB 95, cash flow and bankruptcy. Journal of Economics and Finance, 18 (3), 261-274.

Shumway, T. (2001). Forecasting bankruptcy more accurately: A simple hazard model. The Journal of Business, 74 (1), 101-24.

Sloan, R. (1996). Do stock prices fully reflect information in accruals and cash flows about future earnings? The Accounting Review, 71 (3), 289-315. 
Table 1

Sample Construction

Panel A: Number of entities by year

\begin{tabular}{|c|c|c|c|c|c|c|}
\hline \multirow{2}{*}{$\begin{array}{l}\text { Sample period } \\
\text { (fiscal year) }\end{array}$} & \multicolumn{3}{|c|}{ Banks (SIC code 602) } & \multicolumn{3}{|c|}{ Industrial firms (other SIC codes) } \\
\hline & Profit & Loss & All & Profit & Loss & All \\
\hline 2004 & 404 & 9 & 413 & 2,081 & 844 & 2,925 \\
\hline 2005 & 401 & 9 & 410 & 2,054 & 802 & 2,856 \\
\hline 2006 & 392 & 6 & 398 & 2,049 & 789 & 2,838 \\
\hline 2007 & 352 & 30 & 382 & 1,927 & 802 & 2,729 \\
\hline 2008 & 245 & 119 & 364 & 1,555 & 863 & 2,418 \\
\hline 2009 & 183 & 143 & 326 & 1,481 & 888 & 2,369 \\
\hline 2010 & 224 & 79 & 303 & 1,701 & 628 & 2,329 \\
\hline 2011 & 281 & 40 & 321 & 1,899 & 688 & 2,587 \\
\hline 2012 & 283 & 27 & 310 & 1,795 & 761 & 2,556 \\
\hline 2013 & 291 & 13 & 304 & 1,750 & 854 & 2,604 \\
\hline 2014 & 306 & 7 & 313 & 1,728 & 928 & 2,656 \\
\hline 2015 & 301 & 6 & 307 & 1,544 & 999 & 2,543 \\
\hline 2016 & 294 & 5 & 299 & 1,489 & 950 & 2,439 \\
\hline All & 3,957 & 493 & 4,450 & 23,053 & 10,796 & 33,849 \\
\hline Number of entities & & & 594 & & & 5,217 \\
\hline
\end{tabular}

Panel B: Number of industrial firms and firm-year observations by SIC codes

\begin{tabular}{llrr}
\hline SIC Codes & Industry & Firms & Firm-years \\
\hline $0100-0999$ & Agriculture, forestry and fishing & 20 & 112 \\
$1000-1499$ & Mining & 291 & 1,739 \\
$1500-1799$ & Construction & 72 & 516 \\
$2000-3999$ & Manufacturing & 2,653 & 17,397 \\
$4000-4999$ & Transportation, communications, electric, gas and sanitary service & 446 & 2,598 \\
$5000-5199$ & Wholesale trade & 205 & 1,301 \\
$5200-5999$ & Retail trade & 396 & 2,792 \\
$7000-8999$ & Services & 1,262 & 7,173 \\
$9900-9999$ & Other & \multicolumn{8}{|c}{} & 221 \\
& Total & $5,434 *$ & 33,849 \\
\hline
\end{tabular}

The initial sample is U.S. publicly-listed entities in Compustat Bank (banks) and Compustat (industrial firms) from 2004 to 2016. The final sample satisfies the following selection criteria: (i) required data are available; (ii) share price of more than $\$ 1$; and (iii) positive book value of equity.

* The total number of industrial firms in Panel B differs from that in Panel A because firms may acquire different SIC codes over time; these firms are counted multiple times in Panel B, but only once in Panel A. 
Table 2

Descriptive Statistics

\section{Panel A: Firm characteristics}

\begin{tabular}{lrrrrrrr}
\hline $\begin{array}{l}\text { (\$ millions, except } \\
\text { leverage; unwinsorized) }\end{array}$ & Mean & Std. Dev. Minimum & $\begin{array}{r}\text { 1st } \\
\text { quartile }\end{array}$ & Median & 3rd \\
quartile & Maximum \\
\hline Banks & & & & & & & \\
Market capitalization & 2,299 & 14,255 & 2.099 & 74.069 & 214.02 & 777.28 & 308,768 \\
Book value of equity & 1,868 & 13,036 & 0.683 & 68.643 & 150.19 & 523.92 & 241,620 \\
Total assets & 19,011 & 136,347 & 50.79 & 798.71 & 1,729 & 5,188 & $2,573,126$ \\
Leverage & 0.901 & 0.031 & 0.100 & 0.887 & 0.903 & 0.918 & 0.976 \\
Industrial firms & & & & & & & \\
Market capitalization & 4,217 & 17,363 & 1.110 & 150.14 & 575.87 & 2,210 & 629,010 \\
Book value of equity & 1,513 & 6,565 & 0.044 & 70.537 & 248.06 & 880.87 & 283,001 \\
Total assets & 4,634 & 22,754 & 0.423 & 129.80 & 520.00 & 2,151 & 797,769 \\
Leverage & 0.465 & 0.222 & 0.001 & 0.289 & 0.464 & 0.626 & 1.026 \\
\hline
\end{tabular}

\section{Panel B: Variables for regressions 2-4}

\begin{tabular}{lrrrrrrr}
\hline $\begin{array}{l}\text { (Scaled by lagged total } \\
\text { assets; winsorized) }\end{array}$ & Mean & Std. Dev. Minimum & $\begin{array}{c}\text { 1st } \\
\text { quartile }\end{array}$ & Median & 9uartile & Maximum \\
\hline Banks & & & & & & & \\
$M V($ also in model 5) & 0.145 & 0.074 & 0.001 & 0.093 & 0.139 & 0.189 & 0.337 \\
$B V($ also in model 5) & 0.104 & 0.032 & 0.002 & 0.084 & 0.100 & 0.119 & 0.214 \\
$N I$ (also in model 5) & 0.007 & 0.009 & -0.035 & 0.005 & 0.009 & 0.012 & 0.052 \\
$O P A$ & -0.007 & 0.015 & -0.067 & -0.010 & -0.005 & -0.001 & 0.069 \\
$I F$ & 0.010 & 0.033 & -0.251 & -0.003 & 0.009 & 0.023 & 0.208 \\
$O I F$ & 0.003 & 0.032 & -0.279 & -0.008 & 0.004 & 0.016 & 0.210 \\
$C F O$ & 0.014 & 0.013 & -0.091 & 0.010 & 0.014 & 0.019 & 0.091 \\
$\Delta C$ & 0.004 & 0.031 & -0.203 & -0.008 & 0.005 & 0.016 & 0.273 \\
Industrial firms & & & & & & & \\
$M V$ & 1.920 & 2.193 & 0.003 & 0.669 & 1.213 & 2.237 & 13.974 \\
$B V$ & 0.602 & 0.350 & 0.000 & 0.374 & 0.561 & 0.766 & 2.390 \\
$N I$ & -0.015 & 0.228 & -1.229 & -0.031 & 0.038 & 0.084 & 1.295 \\
$O P A$ & -0.069 & 0.119 & -2.335 & -0.107 & -0.057 & -0.021 & 2.238 \\
$I F$ & 0.077 & 0.182 & -2.457 & 0.016 & 0.063 & 0.125 & 2.594 \\
$O I F$ & 0.008 & 0.189 & -2.744 & -0.052 & 0.012 & 0.068 & 2.783 \\
$C F O$ & 0.054 & 0.198 & -0.994 & 0.025 & 0.086 & 0.144 & 1.192 \\
$\Delta C$ & -0.023 & 0.250 & -1.515 & -0.037 & 0.013 & 0.067 & 1.514 \\
\hline
\end{tabular}


Table 2

Descriptive Statistics (Continued)

Panel C: Correlations between variables for regressions 2-4

\begin{tabular}{|c|c|c|c|c|c|c|c|}
\hline & $B V$ & $N I$ & $O P A$ & $I F$ & OIF & $\mathrm{CFO}$ & $\Delta C$ \\
\hline \multicolumn{8}{|l|}{$\underline{\text { Banks }}$} \\
\hline$M V$ & $0.551 * * *$ & $0.729 * * *$ & $0.287 * * *$ & $-0.045 * * *$ & $0.091 * * *$ & $0.232 * * *$ & $0.136 * * *$ \\
\hline$B V$ & & $0.372 * * *$ & $0.134 * * *$ & -0.011 & $0.064 * * *$ & $0.145 * * *$ & $0.070 * * *$ \\
\hline$N I$ & $0.392 * * *$ & & $0.367 * * *$ & $-0.025^{*}$ & $0.153 * * *$ & $0.326^{* * *}$ & $0.142 * * *$ \\
\hline$O P A$ & $0.182 * * *$ & $0.514 * * *$ & & $-0.278 * * *$ & $0.139 * * *$ & $-0.652 * * *$ & 0.003 \\
\hline$I F$ & -0.008 & 0.024 & $-0.272 * * *$ & & $0.851 * * *$ & $0.289 * * *$ & $-0.878 * * *$ \\
\hline OIF & $0.075 * * *$ & $0.261 * * *$ & $0.182 * * *$ & $0.897 * * *$ & & -0.001 & $-0.921 * * *$ \\
\hline$C F O$ & $0.080 * * *$ & $0.144 * * *$ & $-0.775^{* * *}$ & $0.332 * * *$ & -0.017 & & $0.091 * * *$ \\
\hline$\Delta C$ & $0.042 * * *$ & $0.034 * *$ & $-0.031 * *$ & $-0.921 * * *$ & $-0.956^{* * *}$ & $0.062 * * *$ & \\
\hline \multicolumn{8}{|c|}{ Industrial firms } \\
\hline$M V$ & $0.536 * * *$ & $0.299 * * *$ & $-0.042 * * *$ & $0.196 * * *$ & $0.198 * * *$ & $0.250 * * *$ & $0.058 * * *$ \\
\hline$B V$ & & $0.197 * * *$ & $0.042 * * *$ & $0.202 * * *$ & $0.266^{* * *}$ & $0.117 * * *$ & $-0.046^{* * *}$ \\
\hline$N I$ & $-0.164 * * *$ & & $0.362 * * *$ & $0.167 * * *$ & $0.412 * * *$ & $0.728 * * *$ & $0.507 * * *$ \\
\hline$O P A$ & $-0.040 * * *$ & $0.492 * * *$ & & $-0.283 * * *$ & $0.371 * * *$ & $-0.228 * * *$ & $0.034 * * *$ \\
\hline$I F$ & $0.318 * * *$ & $-0.022 * * *$ & $-0.269 * * *$ & & $0.684 * * *$ & $0.378 * * *$ & $-0.417 * * *$ \\
\hline OIF & $0.282 * * *$ & $0.289 * * *$ & $0.372 * * *$ & $0.794 * * *$ & & $0.161 * * *$ & $-0.406^{* * *}$ \\
\hline$C F O$ & $-0.164 * * *$ & $0.853 * * *$ & $-0.034 * * *$ & $0.135^{* * *}$ & $0.109 * * *$ & & $0.539 * * *$ \\
\hline$\Delta C$ & $-0.361 * * *$ & $0.693 * * *$ & $0.168 * * *$ & $-0.619 * * *$ & $-0.490 * * *$ & $0.695 * * *$ & \\
\hline
\end{tabular}

\section{Panel D: Additional variables for bank-only regression 5}

\begin{tabular}{lrrrrrrr}
\hline $\begin{array}{l}\text { (Scaled by lagged total } \\
\text { assets; winsorized) }\end{array}$ & Mean & Std. Dev. & Minimum & $\begin{array}{r}\text { 1st } \\
\text { quartile }\end{array}$ & Median & 3rd \\
\hline LOAN_HFS & 0.000 & 0.009 & -0.049 & -0.001 & 0.000 & 0.000 & 0.049 \\
LLP & -0.005 & 0.007 & -0.034 & -0.005 & -0.002 & -0.001 & 0.013 \\
SEC_GL & 0.000 & 0.001 & -0.006 & 0.000 & 0.000 & 0.000 & 0.006 \\
TRAD_OTH & 0.000 & 0.005 & -0.022 & -0.002 & 0.000 & 0.002 & 0.022 \\
OTHER_O & -0.002 & 0.008 & -0.074 & -0.004 & -0.002 & 0.000 & 0.064 \\
LOAN_HFI & 0.040 & 0.065 & -0.176 & 0.000 & 0.017 & 0.071 & 0.265 \\
SINV & 0.006 & 0.039 & -0.140 & -0.008 & 0.000 & 0.019 & 0.149 \\
DEPOSIT & -0.046 & 0.075 & -0.290 & -0.081 & -0.036 & -0.002 & 0.217 \\
DEBT & -0.004 & 0.038 & -0.132 & -0.020 & 0.000 & 0.012 & 0.132 \\
OTHER_IF & 0.014 & 0.048 & -0.339 & -0.002 & 0.003 & 0.021 & 0.403 \\
\hline
\end{tabular}

Panel A reports statistics for unwinsorized firm characteristics at the fiscal year end; leverage is total liabilities divided by total assets. In Panels B-D, regression variables are scaled by lagged total assets and winsorized by extreme $2 \%$. $M V$ is market value of equity at the end of the fourth month after the fiscal year end (= an entity's market value at the fiscal year end times the stock return over subsequent four months); $B V$ is book value of common equity; $N I$ is income before extraordinary items; $O P A$ is operating accruals; $I F$ is investing and non-shareholder financing items; $O I F=O P A+I F$; $C F O$ is cash flow from operations; $\triangle C$ is non-shareholder change in cash. In Panel $\mathrm{C}$, Pearson (Spearman) correlations are above (below) the diagonal. ***,**, and * indicate statistical significance at the $1 \%, 5 \%$, and $10 \%$ levels, respectively, in two-tailed tests. Panel D reports additional regression variables in Model 5 (equal to the respective SCF items times 1): $L O A N \_H F S$ is change in loans held-for-sale; $L L P$ is loan loss provision; SEC_GL is investment security gains and losses; TRAD_OTH is net change in trading and other assets and liabilities; OTHER_O is other operating accruals; $L O A N \_H F I$ is change in loans held for investment; SINV is change in investments; DEPOSIT is change in deposits; DEBT 
is change in debt; OTHER_IF is other investing and financing items. The Appendix provides details of variable construction. 
Table 3

Value Relevance of Aggregate Items in Statements of Cash Flows: Banks vs. Industrial Firms

Panel A: The overall sample period (2004-2016)

\begin{tabular}{|c|c|c|c|c|c|c|c|c|c|}
\hline \multirow{3}{*}{$\begin{array}{l}\text { Independent } \\
\text { variables }\end{array}$} & \multicolumn{9}{|c|}{ Dependent: $M V$} \\
\hline & \multicolumn{3}{|c|}{ Model (2) } & \multicolumn{3}{|c|}{ Model (3) } & \multicolumn{3}{|c|}{ Model (4) } \\
\hline & Banks & Industrial & $\operatorname{Diff}(p)$ & Banks & Industrial & $\operatorname{Diff}(p)$ & Banks & Industrial & $\operatorname{Diff}(p)$ \\
\hline \multirow[t]{2}{*}{ Intercept } & $0.026 * * *$ & -0.070 & 0.027 & $0.027 * * *$ & $0.139 * * *$ & 0.072 & $0.026 * * *$ & -0.070 & 0.029 \\
\hline & $(4.83)$ & $(-1.31)$ & & $(5.06)$ & $(2.74)$ & & $(4.85)$ & $(-1.32)$ & \\
\hline \multirow[t]{2}{*}{$O P A(-)$} & $-0.160 * *$ & $-3.992 * * *$ & $<0.01$ & & & & $-0.192 * *$ & $-3.987 * * *$ & $<0.01$ \\
\hline & $(-1.99)$ & $(-11.56)$ & & & & & $(-2.27)$ & $(-11.65)$ & \\
\hline \multirow[t]{2}{*}{ OIF } & & & & -0.041 & $-0.688 * * *$ & $<0.01$ & & & \\
\hline & & & & $(-1.56)$ & $(-3.60)$ & & & & \\
\hline \multirow[t]{2}{*}{$I F$} & & & & & & & -0.037 & 0.008 & 0.821 \\
\hline & & & & & & & $(-1.43)$ & $(0.04)$ & \\
\hline \multirow[t]{2}{*}{$N I(+)$} & $6.056^{* * *}$ & $9.364 * * *$ & $<0.01$ & $5.991 * * *$ & $8.140 * * *$ & $<0.01$ & $6.068 * * *$ & $9.362 * * *$ & $<0.01$ \\
\hline & $(14.59)$ & $(26.18)$ & & $(14.59)$ & $(21.03)$ & & $(14.66)$ & $(25.34)$ & \\
\hline \multirow[t]{2}{*}{$B V(+)$} & $0.912 * * *$ & $2.045 * * *$ & $<0.01$ & $0.913 * * *$ & $2.180 * * *$ & $<0.01$ & $0.911 * * *$ & $2.044 * * *$ & $<0.01$ \\
\hline & $(23.16)$ & $(23.48)$ & & $(23.18)$ & $(24.52)$ & & $(23.10)$ & $(23.69)$ & \\
\hline \multirow[t]{2}{*}{ LOSS } & 0.009 & $-0.484 * * *$ & & 0.008 & $-0.548 * * *$ & & 0.009 & $-0.393 * * *$ & \\
\hline & $(0.61)$ & $(-5.20)$ & & $(0.57)$ & $(-5.92)$ & & $(0.61)$ & $(-4.19)$ & \\
\hline \multirow[t]{2}{*}{$O P A \times \operatorname{LOSS}(+)$} & 0.233 & $3.589 * * *$ & $<0.01$ & & & & $0.276^{*}$ & $4.052 * * *$ & $<0.01$ \\
\hline & $(1.44)$ & $(8.48)$ & & & & & $(1.70)$ & $(9.37)$ & \\
\hline \multirow[t]{2}{*}{$O I F \times L O S S$} & & & & 0.057 & $1.478 * * *$ & $<0.01$ & & & \\
\hline & & & & $(1.38)$ & $(6.19)$ & & & & \\
\hline \multirow[t]{2}{*}{$I F \times L O S S$} & & & & & & & 0.051 & $0.919 * * *$ & $<0.01$ \\
\hline & & & & & & & $(1.25)$ & (3.64) & \\
\hline \multirow[t]{2}{*}{$N I \times \operatorname{LOSS}(-)$} & $-6.242 * * *$ & $-13.188 * * *$ & $<0.01$ & $-6.116^{* * *}$ & $-12.278 * * *$ & $<0.01$ & $-6.270 * * *$ & $-13.337 * * *$ & $<0.01$ \\
\hline & $(-13.21)$ & $(-33.44)$ & & $(-13.83)$ & $(-29.43)$ & & $(-13.30)$ & $(-32.84)$ & \\
\hline \multirow[t]{2}{*}{$B V \times \operatorname{LOSS}(+)$} & 0.050 & $0.952 * * *$ & 0.017 & 0.049 & $0.630 * * *$ & 0.535 & 0.051 & $0.749 * * *$ & 0.045 \\
\hline & $(0.79)$ & $(8.22)$ & & $(0.76)$ & $(5.20)$ & & $(0.80)$ & $(6.30)$ & \\
\hline Adjusted $R^{2}$ & 0.706 & 0.513 & & 0.706 & 0.500 & & 0.706 & 0.516 & \\
\hline \multirow{2}{*}{$\begin{array}{l}\text { Number of Obs. } \\
\text { Specifications }\end{array}$} & 4,450 & 33,849 & & 4,450 & 33,849 & & 4,450 & 33,849 & \\
\hline & \multicolumn{9}{|c|}{ Year fixed effect; White standard error clustered by firm } \\
\hline
\end{tabular}

\begin{tabular}{lcr}
\multicolumn{3}{c}{ Equality tests of coefficients in Model $4(p)$} \\
\hline Coefficient pair & Banks & Industrial \\
\hline$O P A$ vs. $I F$ & 0.054 & $<0.01$ \\
$O P A \times L O S S$ vs. $I F \times L O S S$ & 0.167 & $<0.01$ \\
\hline
\end{tabular}


Panel B: The pre-crisis period (2004-2006)

\begin{tabular}{|c|c|c|c|c|c|c|c|c|c|}
\hline \multirow{3}{*}{$\begin{array}{l}\text { Independent } \\
\text { variables }\end{array}$} & \multicolumn{9}{|c|}{ Dependent: $M V$} \\
\hline & \multicolumn{3}{|c|}{ Model (2) } & \multicolumn{3}{|c|}{ Model (3) } & \multicolumn{3}{|c|}{ Model (4) } \\
\hline & Banks & Industrial & $\operatorname{Diff}(p)$ & Banks & Industrial & $\operatorname{Diff}(p)$ & Banks & Industrial & $\operatorname{Diff}(p)$ \\
\hline Intercept & $\begin{array}{l}0.025^{* * * *} \\
(2.79)\end{array}$ & $\begin{array}{l}-0.461 * * * \\
(-8.06)\end{array}$ & $<0.01$ & $\begin{array}{l}0.025^{* * *} \\
(2.80)\end{array}$ & $\begin{array}{l}-0.304 * * * \\
(-5.32)\end{array}$ & $<0.01$ & $\begin{array}{l}0.025^{* * *} \\
(2.75)\end{array}$ & $\begin{array}{l}-0.460 * * * \\
(-8.01)\end{array}$ & $<0.01$ \\
\hline$O P A(-)$ & $\begin{array}{l}-0.078 \\
(-0.71)\end{array}$ & $\begin{array}{l}-3.231 * * * \\
(-10.50)\end{array}$ & $<0.01$ & & & & $\begin{array}{l}-0.024 \\
(-0.20)\end{array}$ & $\begin{array}{l}-3.182 * * * \\
(-8.89)\end{array}$ & $<0.01$ \\
\hline OIF & & & & $\begin{array}{l}0.049 \\
(0.90)\end{array}$ & $\begin{array}{l}-0.489 * * \\
(-2.23)\end{array}$ & 0.017 & & & \\
\hline IF & & & & & & & $\begin{array}{l}0.047 \\
(0.86)\end{array}$ & $\begin{array}{l}0.070 \\
(0.32)\end{array}$ & 0.917 \\
\hline$N I(+)$ & $\begin{array}{l}7.546^{* * * *} \\
(12.33)\end{array}$ & $\begin{array}{l}10.523 * * * \\
(22.46)\end{array}$ & $<0.01$ & $\begin{array}{l}7.525^{* * * *} \\
(12.37)\end{array}$ & $\begin{array}{l}10.050 * * * \\
(19.65)\end{array}$ & 0.001 & $\begin{array}{l}7.536^{* * * *} \\
(12.32)\end{array}$ & $\begin{array}{l}10.504 * * * \\
(21.55)\end{array}$ & $<0.01$ \\
\hline$B V(+)$ & $\begin{array}{l}0.854 * * * \\
(13.09)\end{array}$ & $\begin{array}{l}2.021 * * * \\
(20.04)\end{array}$ & $<0.01$ & $\begin{array}{l}0.855^{* * * *} \\
(13.17)\end{array}$ & $\begin{array}{l}2.098^{* * * *} \\
(20.13)\end{array}$ & $<0.01$ & $\begin{array}{l}0.854 * * * \\
(13.15)\end{array}$ & $\begin{array}{l}2.013 * * * \\
(20.13)\end{array}$ & $<0.01$ \\
\hline LOSS & $\begin{array}{r}0.019 \\
(0.99)\end{array}$ & $\begin{array}{l}-0.281 * * * \\
(-2.86)\end{array}$ & $<0.01$ & $\begin{array}{r}0.022 \\
(1.17)\end{array}$ & $\begin{array}{l}-0.312^{* * *} \\
(-3.18)\end{array}$ & 0.001 & $\begin{array}{l}0.035^{*} \\
(1.82)\end{array}$ & $\begin{array}{l}-0.178^{*} \\
(-1.78)\end{array}$ & 0.037 \\
\hline$O P A \times \operatorname{LOSS}(+)$ & $\begin{array}{l}0.464 * \\
(1.84)\end{array}$ & $\begin{array}{l}3.309 * * * \\
(7.00)\end{array}$ & $<0.01$ & & & & $\begin{array}{l}0.376 \\
(1.51)\end{array}$ & $\begin{array}{l}3.811 * * * \\
(7.14)\end{array}$ & $<0.01$ \\
\hline$O I F \times L O S S$ & & & & $\begin{array}{l}-0.272^{*} \\
(-1.79)\end{array}$ & $\begin{array}{l}1.515^{* * *} \\
(4.57)\end{array}$ & $<0.01$ & & & \\
\hline$I F \times L O S S$ & & & & & & & $\begin{array}{l}-0.357^{* *} \\
(-2.46)\end{array}$ & $\begin{array}{l}1.054 * * * \\
(3.17)\end{array}$ & $<0.01$ \\
\hline$N I \times \operatorname{LOSS}(-)$ & $\begin{array}{l}-7.574 * * * \\
(-7.32)\end{array}$ & $\begin{array}{l}-14.818 * * * \\
(-27.57)\end{array}$ & $<0.01$ & $\begin{array}{l}-7.528 * * * \\
(-7.40)\end{array}$ & $\begin{array}{l}-14.672 * * * \\
(-25.57)\end{array}$ & $<0.01$ & $\begin{array}{l}-7.242 * * * \\
(-8.42)\end{array}$ & $\begin{array}{l}-15.047 * * * \\
(-26.96)\end{array}$ & $<0.01$ \\
\hline$B V \times \operatorname{LOSS}(+)$ & $\begin{array}{l}0.361^{* *} \\
(2.30)\end{array}$ & $\begin{array}{l}0.771 * * * \\
(4.91)\end{array}$ & 0.065 & $\begin{array}{l}0.273^{*} \\
(1.90)\end{array}$ & $\begin{array}{l}0.461 * * * \\
(2.79)\end{array}$ & 0.391 & $\begin{array}{l}0.197 \\
(1.35)\end{array}$ & $\begin{array}{l}0.537 * * * \\
(3.31)\end{array}$ & 0.118 \\
\hline Adjusted $R^{2}$ & 0.580 & 0.488 & & 0.580 & 0.476 & & 0.581 & 0.492 & \\
\hline Number of Obs. & 1,221 & 8,619 & & 1,221 & 8,619 & & 1,221 & 8,619 & \\
\hline Specifications & & & ear fixed & effect; White & standard erro & or cluster & d by firm & & \\
\hline
\end{tabular}

\begin{tabular}{lrr}
\multicolumn{2}{c}{ Equality tests of coefficients in Model $4(p)$} \\
\hline Coefficient pair & Banks & Industrial \\
\hline$O P A$ vs. $I F$ & 0.512 & $<0.01$ \\
$O P A \times L O S S$ vs. $I F \times$ LOSS & $<0.01$ & $<0.01$ \\
\hline
\end{tabular}


Panel C: The crisis period (2007-2010)

\begin{tabular}{|c|c|c|c|c|c|c|c|c|c|}
\hline \multirow{3}{*}{$\begin{array}{l}\text { Independent } \\
\text { variables }\end{array}$} & \multicolumn{9}{|c|}{ Dependent: $M V$} \\
\hline & \multicolumn{3}{|c|}{ Model (2) } & \multicolumn{3}{|c|}{ Model (3) } & \multicolumn{3}{|c|}{ Model (4) } \\
\hline & Banks & Industrial & $\operatorname{Diff}(p)$ & Banks & Industrial & $\operatorname{Diff}(p)$ & Banks & Industrial & $\operatorname{Diff}(p)$ \\
\hline \multirow[t]{2}{*}{ Intercept } & -0.009 & $-0.260 * * *$ & $<0.01$ & -0.007 & -0.042 & 0.531 & -0.008 & $-0.263 * * *$ & $<0.01$ \\
\hline & $(-1.11)$ & $(-4.83)$ & & $(-0.83)$ & $(-0.76)$ & & $(-1.00)$ & $(-4.91)$ & \\
\hline \multirow[t]{2}{*}{$O P A(-)$} & $-0.226^{*}$ & $-3.994 * * *$ & $<0.01$ & & & & $-0.313 * *$ & $-4.069 * * *$ & $<0.01$ \\
\hline & $(-1.70)$ & $(-12.34)$ & & & & & $(-2.24)$ & $(-11.89)$ & \\
\hline \multirow[t]{2}{*}{ OIF } & & & & $-0.103 * *$ & $-0.958 * * *$ & $<0.01$ & & & \\
\hline & & & & $(-2.39)$ & $(-4.88)$ & & & & \\
\hline \multirow[t]{2}{*}{$I F$} & & & & & & & $-0.098 * *$ & -0.140 & 0.834 \\
\hline & & & & & & & $(-2.30)$ & $(-0.72)$ & \\
\hline \multirow[t]{2}{*}{$N I(+)$} & $6.869 * * *$ & $8.523 * * *$ & 0.037 & $6.757 * * *$ & $7.831 * * *$ & 0.196 & $6.877 * * *$ & $8.556^{* * *}$ & 0.035 \\
\hline & $(10.13)$ & $(20.62)$ & & $(9.76)$ & $(16.95)$ & & $(10.20)$ & (19.99) & \\
\hline \multirow[t]{2}{*}{$B V(+)$} & $0.721 * * *$ & $1.633 * * *$ & $<0.01$ & $0.727 * * *$ & $1.717 * * *$ & $<0.01$ & $0.721 * * *$ & $1.644 * * *$ & $<0.01$ \\
\hline & $(10.19)$ & $(17.90)$ & & $(10.24)$ & $(18.43)$ & & $(10.16)$ & $(18.59)$ & \\
\hline \multirow[t]{2}{*}{ LOSS } & -0.007 & $-0.258 * * *$ & 0.011 & -0.009 & $-0.367 * * *$ & $<0.01$ & -0.008 & -0.146 & 0.160 \\
\hline & $(-0.64)$ & $(-2.64)$ & & $(-0.82)$ & $(-3.78)$ & & $(-0.70)$ & $(-1.49)$ & \\
\hline \multirow[t]{2}{*}{$O P A \times \operatorname{LOSS}(+)$} & 0.309 & $4.822 * * *$ & $<0.01$ & & & & $0.436^{*}$ & $5.781 * * *$ & $<0.01$ \\
\hline & $(1.40)$ & (11.07) & & & & & $(1.91)$ & (12.19) & \\
\hline \multirow[t]{2}{*}{$O I F \times L O S S$} & & & & $0.142 * *$ & $2.670 * * *$ & $<0.01$ & & & \\
\hline & & & & $(2.39)$ & $(8.66)$ & & & & \\
\hline \multirow[t]{2}{*}{$I F \times L O S S$} & & & & & & & $0.138 * *$ & $1.852 * * *$ & $<0.01$ \\
\hline & & & & & & & $(2.32)$ & $(5.86)$ & \\
\hline \multirow[t]{2}{*}{$N I \times \operatorname{LOSS}(-)$} & $-7.031 * * *$ & $-12.923 * * *$ & $<0.01$ & $-6.867 * * *$ & $-12.627 * * *$ & $<0.01$ & $-7.092 * * *$ & $-13.352 * * *$ & $<0.01$ \\
\hline & $(-9.72)$ & $(-25.62)$ & & $(-9.65)$ & $(-23.26)$ & & $(-9.83)$ & $(-25.56)$ & \\
\hline \multirow[t]{2}{*}{$B V \times \operatorname{LOSS}(+)$} & $0.212 * *$ & $0.707 * * *$ & $<0.01$ & $0.198 * *$ & $0.397 * * *$ & 0.258 & $0.208 * *$ & $0.471 * * *$ & 0.130 \\
\hline & $(2.24)$ & $(4.80)$ & & $(2.11)$ & $(2.66)$ & & $(2.21)$ & $(3.21)$ & \\
\hline Adjusted $R^{2}$ & 0.639 & 0.448 & & 0.639 & 0.436 & & 0.640 & 0.457 & \\
\hline Number of Obs. & 1,375 & 9,845 & & 1,375 & 9,845 & & 1,375 & 9,845 & \\
\hline Specifications & \multicolumn{9}{|c|}{ Year fixed effect; White standard error clustered by firm } \\
\hline
\end{tabular}

\begin{tabular}{lcr}
\multicolumn{2}{c}{ Equality tests of coefficients in Model $4(p)$} \\
\hline Coefficient pair & Banks & Industrial \\
\hline$O P A$ vs. $I F$ & 0.105 & $<0.01$ \\
$O P A \times L O S S$ vs. $I F \times$ LOSS & 0.170 & $<0.01$ \\
\hline
\end{tabular}


Panel D: The post-crisis period (2011-2016)

\begin{tabular}{|c|c|c|c|c|c|c|c|c|c|}
\hline \multirow{3}{*}{$\begin{array}{l}\text { Independent } \\
\text { variables }\end{array}$} & \multicolumn{9}{|c|}{ Dependent: $M V$} \\
\hline & \multicolumn{3}{|c|}{ Model (2) } & \multicolumn{3}{|c|}{ Model (3) } & \multicolumn{3}{|c|}{ Model (4) } \\
\hline & Banks & Industrial & $\operatorname{Diff}(p)$ & Banks & Industrial & $\operatorname{Diff}(p)$ & Banks & Industrial & $\operatorname{Diff}(p)$ \\
\hline \multirow[t]{2}{*}{ Intercept } & $0.029 * * *$ & $-0.191 * *$ & $<0.01$ & $0.030 * * *$ & 0.054 & 0.933 & $0.030 * * *$ & $-0.194 * *$ & $<0.01$ \\
\hline & $(4.24)$ & $(-2.45)$ & & $(4.37)$ & $(0.78)$ & & $(4.23)$ & $(-2.55)$ & \\
\hline \multirow[t]{2}{*}{$O P A(-)$} & -0.082 & $-4.341 * * *$ & $<0.01$ & & & & -0.093 & $-4.385 * * *$ & $<0.01$ \\
\hline & $(-0.68)$ & $(-6.96)$ & & & & & $(-0.76)$ & $(-7.26)$ & \\
\hline \multirow[t]{2}{*}{ OIF } & & & & -0.019 & $-0.762 * *$ & 0.018 & & & \\
\hline & & & & $(-0.53)$ & $(-2.45)$ & & & & \\
\hline \multirow[t]{2}{*}{$I F$} & & & & & & & -0.015 & -0.071 & 0.885 \\
\hline & & & & & & & $(-0.42)$ & $(-0.20)$ & \\
\hline \multirow[t]{2}{*}{$N I(+)$} & $4.396 * * *$ & $9.396 * * *$ & $<0.01$ & $4.349 * * *$ & $7.471 * * *$ & $<0.01$ & $4.405 * * *$ & $9.408 * * *$ & $<0.01$ \\
\hline & $(7.60)$ & $(15.57)$ & & $(7.74)$ & $(12.13)$ & & $(7.65)$ & (15.29) & \\
\hline \multirow[t]{2}{*}{$B V(+)$} & $1.025 * * *$ & $2.244 * * *$ & $<0.01$ & $1.025 * * *$ & $2.448 * * *$ & $<0.01$ & $1.024 * * *$ & $2.254 * * *$ & $<0.01$ \\
\hline & $(20.02)$ & $(15.63)$ & & (19.92) & $(16.95)$ & & (19.89) & $(15.76)$ & \\
\hline \multirow[t]{2}{*}{ LOSS } & 0.008 & $-0.448 * * *$ & & 0.01 & $-0.552 * * *$ & & 0.01 & $-0.375 * * *$ & \\
\hline & $(0.48)$ & $(-3.97)$ & & $(0.56)$ & $(-5.15)$ & & $(0.60)$ & $(-3.32)$ & \\
\hline \multirow[t]{2}{*}{$O P A \times \operatorname{LOSS}(+)$} & -0.095 & $3.514 * * *$ & $<0.01$ & & & & -0.103 & $3.888 * * *$ & $<0.01$ \\
\hline & $(-0.47)$ & (4.89) & & & & & $(-0.54)$ & $(5.46)$ & \\
\hline \multirow[t]{2}{*}{$O I F \times L O S S$} & & & & 0.084 & $1.264 * * *$ & $<0.01$ & & & \\
\hline & & & & $(1.15)$ & $(3.51)$ & & & & \\
\hline \multirow[t]{2}{*}{$I F \times L O S S$} & & & & & & & 0.108 & $0.747 *$ & 0.058 \\
\hline & & & & & & & $(1.42)$ & $(1.89)$ & \\
\hline \multirow[t]{2}{*}{$N I \times \operatorname{LOSS}(-)$} & $-4.568 * * *$ & $-12.88 * * *$ & 0.07 & $-4.61 * * *$ & $-11.265^{* * *}$ & 0.548 & $-4.445 * * *$ & $-12.992 * * *$ & 0.025 \\
\hline & $(-6.29)$ & $(-20.04)$ & & $(-6.60)$ & $(-17.32)$ & & $(-6.24)$ & $(-19.84)$ & \\
\hline \multirow[t]{2}{*}{$B V \times \operatorname{LOSS}(+)$} & -0.118 & $0.95 * * *$ & 0.78 & -0.131 & $0.629 * * *$ & 0.443 & -0.12 & $0.788 * * *$ & 0.772 \\
\hline & $(-1.04)$ & $(5.31)$ & & $(-1.15)$ & $(3.42)$ & & $(-1.07)$ & $(4.32)$ & \\
\hline Adjusted $R^{2}$ & 0.619 & 0.529 & & 0.619 & 0.516 & & 0.619 & 0.531 & \\
\hline Number of Obs. & 1,854 & 15,385 & & 1,854 & 15,385 & & 1,854 & 15,385 & \\
\hline Specifications & \multicolumn{9}{|c|}{ Year fixed effect; White standard error clustered by firm } \\
\hline
\end{tabular}

\begin{tabular}{lcr}
\multicolumn{3}{c}{ Equality tests of coefficients in Model $4(p)$} \\
\hline Coefficient pair & Banks & Industrial \\
\hline$O P A$ vs. $I F$ & 0.523 & $<0.01$ \\
$O P A \times L O S S$ vs. $I F \times$ LOSS & 0.282 & $<0.01$ \\
\hline
\end{tabular}

The table reports the results of estimating regressions (2)-(4). The variables are defined in Table 2. Panels A-D are for the overall sample period (2004-2016), and the sub-periods 2004-2006, 2007-2010, and 2011-2016, respectively. The columns headed "Banks" and "Industrial" report regression statistics for banks and industrial firms, respectively. $t$-statistics (in parentheses) are based on White standard errors that are clustered by firm. ***, **, and * indicate statistical significance at the $1 \%, 5 \%$, and $10 \%$ levels, respectively, in two-tailed tests. The columns headed "Diff $(p)$ " report $p$-values for two-sided equality tests of regression coefficients for banks and industrial firms. At the bottom of each panel, the section "Equality tests of coefficients in Model $4(p)$ " reports $p$-values from two-tailed tests of equality of coefficient pairs in Model (4): $O P A$ vs. $I F$, and $O P A \times L O S S$ vs. $I F \times L O S S$. 
Table 4

Value Relevance of Individual Items in Banks' Statements of Cash Flows

\begin{tabular}{|c|c|c|c|c|}
\hline \multirow[b]{2}{*}{ Independent variables } & \multicolumn{4}{|c|}{ Dependent variable (Model 5): $M V$} \\
\hline & 2004-2016 & 2004-2006 & $2007-2010$ & 2011-2016 \\
\hline Intercept & $0.019 * * *$ & 0.015 & -0.009 & $0.022 * * *$ \\
\hline \multicolumn{5}{|l|}{ Operating items } \\
\hline LOAN_HFS (-) & 0.003 & 0.219 & 0.195 & -0.019 \\
\hline$L L P(-)$ & 0.383 & 0.970 & -0.308 & $1.423 * *$ \\
\hline$S E C \_G L(-)$ & $-2.494 * * *$ & $-4.657 * * *$ & $-2.956 * * *$ & -1.825 \\
\hline TRAD_OTH (-) & 0.210 & $0.629 * *$ & -0.082 & 0.054 \\
\hline OTHER_O(-) & $-0.973 * * *$ & $-1.173 * * *$ & $-0.825 * * *$ & $-0.759 * *$ \\
\hline \multicolumn{5}{|c|}{ Investing and financing items } \\
\hline$L O A N \_H F I$ & 0.035 & $0.155^{* * *}$ & $-0.130 * *$ & $0.138 * * *$ \\
\hline SINV & 0.005 & 0.078 & -0.014 & -0.007 \\
\hline DEPOSIT & $-0.092 * * *$ & -0.045 & -0.068 & $-0.091 * *$ \\
\hline$D E B T$ & 0.005 & 0.100 & -0.023 & 0.000 \\
\hline OTHER_IF & 0.038 & 0.086 & 0.088 & 0.059 \\
\hline$N I(+)$ & $6.186^{* * *}$ & $7.570 * * *$ & $7.266 * * *$ & $4.371 * * *$ \\
\hline$B V(+)$ & $0.896^{* * *}$ & $0.785^{* * *}$ & $0.735 * * *$ & $1.010 * * *$ \\
\hline LOSS & 0.018 & $0.043 * * *$ & -0.007 & 0.020 \\
\hline$L O A N \_H F S \times L O S S(+)$ & 0.170 & 0.398 & 0.154 & -0.334 \\
\hline $\operatorname{LLP} \times \operatorname{LOSS}(+)$ & -0.145 & 1.193 & 0.513 & -1.046 \\
\hline$S E C \_G L \times \operatorname{LOSS}(+)$ & $2.077^{*}$ & 0.075 & $2.275^{*}$ & $6.708^{*}$ \\
\hline$T R A D \_O T H \times \operatorname{LOSS}(+)$ & -0.260 & 0.541 & 0.024 & -0.122 \\
\hline OTHER_O×LOSS $(+)$ & $0.932 * * *$ & 0.473 & $0.829^{* *}$ & $0.818^{*}$ \\
\hline$L O A N \_H F I \times L O S S$ & 0.013 & $-0.511 * * *$ & $0.176^{* *}$ & 0.043 \\
\hline$S I N V \times L O S S$ & 0.070 & $0.202 *$ & 0.076 & 0.153 \\
\hline$D E P O S I T \times L O S S$ & $0.121 * * *$ & $-0.259 * * *$ & $0.114^{*}$ & $0.169^{*}$ \\
\hline$D E B T \times L O S S$ & 0.000 & $-0.214 * *$ & 0.050 & 0.152 \\
\hline OTHER_IF $\times$ LOSS & $-0.112^{*}$ & $-0.631 * * *$ & -0.186 & 0.009 \\
\hline$N I \times \operatorname{LOSS}(-)$ & $-6.332 * * *$ & $-8.978 * * *$ & $-7.423 * * *$ & $-4.893 * * *$ \\
\hline$B V \times \operatorname{LOSS}(+)$ & 0.042 & $0.218^{*}$ & $0.189^{*}$ & -0.097 \\
\hline Adjusted $R^{2}$ & 0.722 & 0.627 & 0.652 & 0.648 \\
\hline Number of observations & 4,450 & 1,221 & 1,375 & 1,854 \\
\hline Other specifications & \multicolumn{4}{|c|}{ Year fixed effect; White standard error clustered by firm } \\
\hline
\end{tabular}

The table reports the results of estimating the regression model 5. The variables are defined in Table 2. $t$-statistics are based on White standard errors that are clustered by firm and omitted for the brevity. $* * *, * *$, and $*$ indicate statistical significance at the $1 \%, 5 \%$, and $10 \%$ levels, respectively, in two-tailed tests. 
Table 5

Statements of Cash Flows and Prediction of Bank Distress

Panel A: Bank distress cases over 2008 to 2010

\begin{tabular}{lr}
\hline Year & Banks \\
\hline 2008 & 0 \\
2009 & 15 \\
2010 & 21 \\
Total distressed banks & 36 \\
Total non-distressed banks & 346 \\
Total banks & 382 \\
Distressed \% & $9.42 \%$ \\
\hline
\end{tabular}

Panel B: Descriptive statistics for regression variables for Model 6: Distressed and non-distressed banks

\begin{tabular}{|c|c|c|c|c|c|c|}
\hline \multirow[b]{2}{*}{ Variables } & \multicolumn{3}{|c|}{ Distressed banks $(\mathrm{N}=36)$} & \multicolumn{3}{|c|}{ Non-distressed banks $(\mathrm{N}=346)$} \\
\hline & Mean & St. Dev. & Median & Mean & St. Dev. & Median \\
\hline \multicolumn{7}{|c|}{ Aggregate SCF items } \\
\hline$O P A$ & -0.432 & 1.886 & -0.322 & -0.425 & 1.249 & -0.343 \\
\hline$I F$ & 2.024 & 3.293 & 1.527 & 1.207 & 2.854 & 0.931 \\
\hline OIF & 1.592 & 3.403 & 1.198 & 0.782 & 2.577 & 0.466 \\
\hline$N I$ & 0.578 & 1.108 & 0.589 & 0.839 & 0.651 & 0.919 \\
\hline \multicolumn{7}{|c|}{ Individual SCF items } \\
\hline$L O A N \_H F S$ & 0.123 & 1.212 & -0.022 & -0.035 & 0.723 & 0.000 \\
\hline$L L P$ & -0.656 & 0.573 & -0.460 & -0.314 & 0.421 & -0.199 \\
\hline$S E C \_G L$ & -0.003 & 0.024 & 0.000 & 0.000 & 0.082 & 0.000 \\
\hline TRAD OTH & 0.196 & 0.427 & 0.077 & 0.123 & 0.539 & 0.041 \\
\hline OTHER_O & -0.092 & 0.808 & -0.039 & -0.199 & 0.623 & -0.157 \\
\hline$L O A N \_H F I$ & 9.003 & 6.400 & 8.532 & 6.423 & 6.541 & 5.181 \\
\hline $\operatorname{SINV}$ & -0.263 & 3.383 & -0.061 & -0.095 & 3.931 & -0.167 \\
\hline DEPOSIT & -3.540 & 8.521 & -4.345 & -2.105 & 6.932 & -1.165 \\
\hline$D E B T$ & -3.595 & 4.204 & -3.558 & -3.163 & 4.268 & -2.639 \\
\hline OTHER_IF & 0.419 & 1.348 & 0.177 & 0.147 & 1.876 & 0.228 \\
\hline \multicolumn{7}{|c|}{ Additional predictors } \\
\hline TARP & 0.056 & 0.232 & 0.000 & 0.546 & 0.499 & 1.000 \\
\hline SIZE & 14.285 & 1.110 & 14.058 & 14.489 & 1.541 & 14.205 \\
\hline TIER 1 & 10.176 & 2.115 & 9.675 & 11.121 & 2.538 & 10.365 \\
\hline$N P L$ & 1.689 & 1.226 & 1.303 & 0.874 & 0.845 & 0.625 \\
\hline LEVERAGE & 91.116 & 2.709 & 91.809 & 90.687 & 1.997 & 90.840 \\
\hline
\end{tabular}


Panel C: Logit model 6 for bank distress prediction

\begin{tabular}{|c|c|c|c|c|}
\hline \multirow{2}{*}{$\begin{array}{l}(\mathrm{N}=382) \\
\text { Predictors }\end{array}$} & \multicolumn{4}{|c|}{ Dependent variable: DISTRESS $_{2008-10}$} \\
\hline & (6.i) & (6.ii) & (6.iii) & (6.iv) \\
\hline$O P A$ & $\begin{array}{l}0.047 \\
(0.29)\end{array}$ & & $\begin{array}{c}0.114 \\
(0.68)\end{array}$ & \\
\hline OIF & & $\begin{array}{c}0.093 \\
(1.30)\end{array}$ & & \\
\hline$I F$ & & & $\begin{array}{c}0.092 \\
(1.28)\end{array}$ & \\
\hline Operating items & & & & \\
\hline$L O A N \_H F S$ & & & & $\begin{array}{l}0.179 \\
(0.70)\end{array}$ \\
\hline$L L P$ & & & & $\begin{array}{l}-0.374 \\
(-0.76)\end{array}$ \\
\hline$S E C_{-} G L$ & & & & $\begin{array}{l}-3.541 \\
(-0.94)\end{array}$ \\
\hline TRAD_OTH & & & & $\begin{array}{l}-0.174 \\
(-0.37)\end{array}$ \\
\hline OTHER_O & & & & $\begin{array}{r}0.470 \\
(1.10)\end{array}$ \\
\hline Investing and fin & & & & \\
\hline$L O A N \_H F I$ & & & & $\begin{array}{l}0.146^{*} \\
(1.81)\end{array}$ \\
\hline SINV & & & & $\begin{array}{l}0.011 \\
(0.12)\end{array}$ \\
\hline DEPOSIT & & & & $\begin{array}{c}0.082 \\
(1.04)\end{array}$ \\
\hline$D E B T$ & & & & $\begin{array}{l}0.051 \\
(0.56)\end{array}$ \\
\hline OTHER_IF & & & & $\begin{array}{l}9.936 \\
(0.86)\end{array}$ \\
\hline$N I(-)$ & $\begin{array}{l}0.143 \\
(0.52)\end{array}$ & $\begin{array}{c}0.076 \\
(0.29)\end{array}$ & $\begin{array}{l}0.060 \\
(0.21)\end{array}$ & $\begin{array}{c}0.147 \\
(0.39)\end{array}$ \\
\hline $\operatorname{TARP}(-)$ & $\begin{array}{l}-3.110^{* * *} \\
(-4.12)\end{array}$ & $\begin{array}{l}-3.094^{* * *} \\
(-4.10)\end{array}$ & $\begin{array}{l}-3.094 * * * \\
(-4.10)\end{array}$ & $\begin{array}{l}-3.298^{* * *} \\
(-4.26)\end{array}$ \\
\hline SIZE (-) & $\begin{array}{l}-0.121 \\
(-0.77)\end{array}$ & $\begin{array}{l}-0.054 \\
(-0.33)\end{array}$ & $\begin{array}{l}-0.054 \\
(-0.33)\end{array}$ & $\begin{array}{c}0.036 \\
(0.21)\end{array}$ \\
\hline TIERl (-) & $\begin{array}{l}-0.321 * * * \\
(-2.75)\end{array}$ & $\begin{array}{l}-0.303^{* *} \\
(-2.54)\end{array}$ & $\begin{array}{l}-0.302 * * \\
(-2.53)\end{array}$ & $\begin{array}{l}-0.240^{*} \\
(-1.92)\end{array}$ \\
\hline$N P L(+)$ & $\begin{array}{l}0.341^{* *} \\
(2.39)\end{array}$ & $\begin{array}{l}0.318^{* *} \\
(2.22)\end{array}$ & $\begin{array}{l}0.317^{* *} \\
(2.21)\end{array}$ & $\begin{array}{l}0.335^{*} \\
(1.83)\end{array}$ \\
\hline LEVERAGE $(+)$ & $\begin{array}{r}-0.056 \\
(-0.56)\end{array}$ & $\begin{array}{l}-0.020 \\
(-0.20)\end{array}$ & $\begin{array}{l}-0.023 \\
(-0.22)\end{array}$ & $\begin{array}{l}0.014 \\
(0.12)\end{array}$ \\
\hline Pseudo $R^{2}$ & 0.249 & 0.256 & 0.256 & 0.298 \\
\hline
\end{tabular}


The sample includes 382 banks that were in existence at the end of 2007. Panel A reports the number of distressed banks in each of 2008, 2009 and 2010. Panel B reports descriptive statistics of regression variables in Model 6. TARP is an indicator variable that equals one if a capital infusion under TARP over 2008-2009 was received and zero otherwise; SIZE is the natural logarithm of total assets denominated in thousands of dollars; TIER1 is tier-1 capital ratio; NPL is non-performing loans divided by total assets; LEVERAGE is total liabilities divided by total assets; the rest variables are defined in Table 2 . All continuous variables (i.e., except TARP) are measured at the end of 2007 and winsorized by $2 \%$ at both tails. All of these variables except TARP and SIZE are multiplied by 100 when used in the estimation. Panel C reports the results of estimating the logit model 6, where the dependent variable DISTRESS $2008-10$ is equal to one if a bank is distressed during the 2008-2010 period, and zero otherwise. $t$-statistics are in parentheses. $* * *, * *$, and $*$ indicate statistical significance at the $1 \%, 5 \%$, and $10 \%$ levels, respectively, in two-tailed tests. 
Part 1: Statement-of-Cash-Flow Items from Compustat Bank Used to Construct the Variables in This Study.

\begin{tabular}{|c|c|c|}
\hline & & Compustat Data Item \\
\hline \multirow[t]{16}{*}{ Operating: } & Income before extraordinary items (cash flow) & IBC \\
\hline & Extraordinary items and discontinued operations (cash flow) & XIDOC \\
\hline & Depreciation and amortization (cash flow) & DPC \\
\hline & Deferred taxes (cash flow) & TXDC \\
\hline & Provision for loan losses & PCLC \\
\hline & Equity in net loss - earnings & ESUBC \\
\hline & Investment security gains/losses & INVSGL \\
\hline & Other gains/losses on sales & OGLOS \\
\hline & Mortgages - decrease (increase) & INVCH \\
\hline & Accounts payable and accrued liabilities - increase (decrease) & APALCH \\
\hline & Accounts receivable - decrease (increase) & $\mathrm{RECCH}$ \\
\hline & Income taxes - accrued - increase (decrease) & TXACH \\
\hline & Excess tax benefit stock options - cash flow operating & TXBCO \\
\hline & Assets and liabilities - other - net change & $\mathrm{AOLOCH}$ \\
\hline & Other operations & OTHOP \\
\hline & ating activities - net cash flow & OANCF \\
\hline \multirow[t]{10}{*}{ Investing: } & Short-term investments - change & IVSTCH \\
\hline & Increase in investments (excluding loans) & -IINVC \\
\hline & Decrease in investments (excluding loans) & DINVC \\
\hline & Increase in loans receivable & -ILREC \\
\hline & Decrease in loans receivable & DLREC \\
\hline & Capital expenditures & -CAPX \\
\hline & Sale of property & SPPE \\
\hline & Acquisitions & $-\mathrm{AQC}$ \\
\hline & Investing activities - other & IVACO \\
\hline & ting activities - net cash flow & IVNCF \\
\hline \multirow[t]{10}{*}{ Financing: } & Deposits - net change & $\mathrm{DEPCH}$ \\
\hline & Purchase of common and preferred stock & -PRSTKC \\
\hline & Sale of common and preferred stock & SSTK \\
\hline & Cash dividends (cash flow) & $-\mathrm{DV}$ \\
\hline & Long-term debt - issuance & DLTIS \\
\hline & Long-term debt - reduction & -DLTR \\
\hline & Current debt - changes & $\mathrm{DLCCH}$ \\
\hline & Excess tax benefit of stock options-cash flow financing & TXBCOF \\
\hline & Financing activities - other & OFA \\
\hline & cing activities - net cash flow & FINCF \\
\hline \multicolumn{2}{|c|}{ Exchange rate effect } & EXRE \\
\hline \multicolumn{2}{|c|}{ Cash and cash equivalents - increase (decrease) } & $\mathrm{CHECH}$ \\
\hline
\end{tabular}


APPENDIX: STATEMENTS OF CASH FLOWS: COMPUSTAT DATA ITEMS AND CONSTRUCTION OF REGRESSION VARIABLES - CONTINUED

Part 2: Construction of Statement-of-Cash-Flow (SCF) Variables from Compustat Bank Items.

\begin{tabular}{|c|c|c|c|}
\hline \multicolumn{2}{|c|}{ Variables (all scaled by lagged total assets) } & \multirow[t]{2}{*}{ Regression models } & \multirow{2}{*}{$\begin{array}{l}\text { Compustat data items (see Part } 1 \text { of the Appendix) or, } \\
\text { in italic font, variables from which the item is } \\
\text { constructed }\end{array}$} \\
\hline Name & Notation & & \\
\hline Income before extraordinary items (NI) & $N I$ & $(2),(3),(4),(5),(6)$ & IBC \\
\hline Operating accruals & $O P A$ & $(2),(4),(6)$ & $\begin{array}{l}\text { IBC - OANCF }+ \text { EXRE }(\times-1) \\
\text { where EXRE }(\times-1) \text { is treated as an operating accrual } \\
\text { and EXRE is effectively treated as part of cash flow } \\
\text { from operations }(\mathrm{CFO}) \text {. }\end{array}$ \\
\hline $\begin{array}{l}\text { The element of } O I F \text { made up of SCF items } \\
\text { categorized as 'investing' or 'financing' }\end{array}$ & $I F$ & (4). (6) & $\begin{array}{l}\text { IVNCF }(\times-1) \\
+(\text { FINCF }- \text { SSTK }+ \text { PRSTKC }+ \text { DV })(\times-1) \\
\text { where financing items are stated exclusive of } \\
\text { shareholder cash flows by subtracting issues of stock } \\
(\text { SSTK) and adding back purchases of stock } \\
\text { (PRSTKC) and dividends (DV). }\end{array}$ \\
\hline $\begin{array}{l}\text { The excess of NI over nonshareholder change in } \\
\text { cash }\end{array}$ & $O I F(=O P A+I F)$ & $(3),(6)$ & IBC - (CHECH-SSTK+PRSTKC+DV) \\
\hline \multicolumn{4}{|l|}{ Components of OPA: } \\
\hline Increase (decrease) in loans held-for-sale & LOAN_HFS & $(5),(6)$ & $\operatorname{INVCH}(\times-1)$ \\
\hline Loan-loss provision & $L L P$ & $(5),(6)$ & $\operatorname{PCLC}(\times-1)$ \\
\hline Investment security gains and losses & $S E C \_G L$ & $(5),(6)$ & $\operatorname{INVSGL}(\times-1)$ \\
\hline $\begin{array}{l}\text { Net increase (decrease) in trading and other } \\
\text { assets and liabilities }\end{array}$ & $T R A D \_O T H$ & $(5),(6)$ & $\mathrm{AOLOCH}(\times-1)$ \\
\hline Other operating accruals & OTHER_O & $(5),(6)$ & $\begin{array}{l}\text { Equal to } O P A \text { less the sum of } L O A N_{-} H F S, L L P \text {, } \\
S E C \_G L \text { and TRAD_OTH }\end{array}$ \\
\hline \multicolumn{4}{|l|}{ Components of OIF: } \\
\hline Increase (decrease) in loans held for investment & $L O A N \_H F I$ & $(5),(6)$ & $($ DLREC - ILREC $)(\times-1)$ \\
\hline Increase (decrease) in investments & SINV & $(5),(6)$ & $($ IVSTCH - IINVC + DINVC) $(\times-1)$ \\
\hline Decrease (increase) in deposits & DEPOSIT & $(5),(6)$ & $\mathrm{DEPCH}(\times-1)$ \\
\hline Decrease (increase) in current and long-term debt & $D E B T$ & $(5),(6)$ & $($ DLTIS - DLTR + DLCCH $)(\times-1)$ \\
\hline Other investing and financing items & OTHER_IF & $(5),(6)$ & $\begin{array}{l}\text { Equal to } I F \text { less the sum of } L O A N_{-} H F I, S I N V \text {, } \\
\text { DEPOSIT and DEBT }\end{array}$ \\
\hline \multicolumn{4}{|l|}{$\begin{array}{l}\text { Cash flow items referred to in model } \\
\text { development but not used in regression models: }\end{array}$} \\
\hline Cash flow from operations & $\mathrm{CFO}$ & None & $\begin{array}{l}\text { Equal to } N I \text { less } O P A \\
\text { Equal to OANCF plus EXRE }\end{array}$ \\
\hline Nonshareholder change in cash & $\Delta C$ & None & $\begin{array}{l}\text { Equal to } N I \text { less } O I F \\
\text { Equal to CHECH plus PRSTK less SSTK plus DV }\end{array}$ \\
\hline
\end{tabular}


APPENDIX: STATEMENTS OF CASH FLOWS: COMPUSTAT DATA ITEMS AND CONSTRUCTION OF REGRESSION VARIABLES - CONTINUED

Part 2 (Continued): Construction of Statement-of-Cash-Flow (SCF) Variables from Compustat Bank Items

Notes to Part 2:

1. Data items available from Compustat Bank are used to construct regression variables for banks for use in regression models (2) to (6). The subset of items that are required for industrial firms for models (2) to (4) are also available in Compustat. Some data items for models (5) and (6), which are estimated for banks only, are not available for industrial firms.

2. All items referred to above (except NI) are defined such that they are added to the relevant cash-flow construct to give NI. For example, cash flow from operations $(=\mathrm{OANCF}+\mathrm{EXRE})$ plus operating accruals $(=\mathrm{IBC}-\mathrm{OANCF}+\mathrm{EXRE}(\times-1))$ equals NI $(=\mathrm{IBC})$. 
APPENDIX: STATEMENTS OF CASH FLOWS: COMPUSTAT DATA ITEMS AND CONSTRUCTION OF REGRESSION VARIABLES - CONTINUED

Part 3: Construction of Variables Other Than Statement-of-Cash-Flow (SCF) variables.

\begin{tabular}{|l|l|l|}
\hline Variable name & Label & Calculation \\
\hline Market value of equity (scaled by total assets) & $M V$ & $\begin{array}{l}\text { (P×SHROUT) } \times \text { the return on the share up to 4 months after the fiscal year end (from } \\
\text { CRSP) }\end{array}$ \\
\hline Book value of equity (scaled by total assets) & BV & CEQ (from Compustat Bank, and from Compustat for industrial firms) \\
\hline Total assets (used to scale other variables) & SIZE (Note) & AT (from Compustat Bank, and from Compustat for industrial firms) \\
\hline Indicator variable for loss firms & LOSS & Equals 1 if the firm reported a loss and 0 otherwise \\
\hline Indicator variable for TARP recipients & TARP & Equals 1 if a capital infusion under TARP was received and 0 otherwise \\
\hline Tier 1 capital ratio & TIER1 & CAPR1 (from Compustat Bank) \\
\hline Non-performing loans (scaled by total assets) & NPL & NPAT (from Compustat Bank) \\
\hline Leverage & LEVERAGE & LT/AT (from Compustat Bank) \\
\hline
\end{tabular}

Note to Part 3:

When used as a regression variable, SIZE is measured as the log of total assets. 